\title{
A metal-free organic-inorganic aqueous flow battery
}

\section{Citation}

Huskinson, Brian, Michael P. Marshak, Changwon Suh, S?leyman Er, Michael R. Gerhardt, Cooper J. Galvin, Xudong Chen, Alán Aspuru-Guzik, Roy G. Gordon, and Michael J. Aziz. 2014. A metal-free organic-inorganic aqueous flow battery. Nature 505(7482): 195-198.

\section{Published Version}

doi:10.1038/nature12909

\section{Permanent link}

http://nrs.harvard.edu/urn-3:HUL.InstRepos:11688785

\section{Terms of Use}

This article was downloaded from Harvard University's DASH repository, and is made available under the terms and conditions applicable to Open Access Policy Articles, as set forth at http:// nrs.harvard.edu/urn-3:HUL.InstRepos:dash.current.terms-of-use\#OAP

\section{Share Your Story}

The Harvard community has made this article openly available.

Please share how this access benefits you. Submit a story.

Accessibility 
This paper can be cited as: B. Huskinson, M.P. Marshak, C. Suh, S. Er, M.R. Gerhardt, C.J. Galvin, X. Chen, A. Aspuru-Guzik, R.G. Gordon and M.J. Aziz, "A metal-free organicinorganic aqueous flow battery”, Nature 505, 195-198 (2014).

The formatted version of this manuscript can be found at the following link:

http://www.nature.com/nature/journal/v505/n7482/full/nature12909.html

\section{A metal-free organic-inorganic aqueous flow battery}

Brian Huskinson ${ }^{1}$, Michael P. Marshak ${ }^{1,2 *}$, Changwon $\mathrm{Suh}^{2}$, Süleyman $\mathrm{Er}^{2,3}$, Michael R.

Gerhardt ${ }^{1}$, Cooper J. Galvin ${ }^{2}$, Xudong Chen ${ }^{2}$, Alán Aspuru-Guzik ${ }^{2}$, Roy G. Gordon ${ }^{1,2} \&$ Michael

J. Aziz ${ }^{1}$

${ }^{1}$ Harvard School of Engineering and Applied Sciences, 29 Oxford Street, Cambridge,

Massachusetts 02138, USA.

${ }^{2}$ Department of Chemistry and Chemical Biology, Harvard University, 12 Oxford Street,

Cambridge, Massachusetts 02138, USA.

${ }^{3}$ Molecular Materials and Nanosystems, Eindhoven University of Technology, PO Box 513,

5600 MB Eindhoven, The Netherlands.

*These authors contributed equally to this work.

As the fraction of electricity generation from intermittent renewable sources-such as solar or wind-grows, the ability to store large amounts of electrical energy is of increasing importance. Solid-electrode batteries maintain discharge at peak power for far too short a time to fully regulate wind or solar power output ${ }^{1,2}$. In contrast, flow batteries can independently scale the power (electrode area) and energy (arbitrarily large storage volume) components of the system by maintaining all of the electro-active species in fluid form $^{3-5}$. Wide-scale utilization of flow batteries is, however, limited by the abundance and cost of these materials, particularly those using redox-active metals and precious metal electrocatalysts ${ }^{6,7}$. Here we describe a class of energy storage materials that exploits the favourable chemical and electrochemical properties of a family of molecules known as quinones. The example we demonstrate is a metal-free flow battery based on the redox chemistry of 9,10-anthraquinone-2,7-disulphonic acid (AQDS). AQDS undergoes extremely rapid and reversible two-electron two-proton reduction on a glassy carbon electrode in sulphuric acid. An aqueous flow battery with inexpensive carbon electrodes, combining the quinone/hydroquinone couple with the $\mathrm{Br}_{2} / \mathrm{Br}$ redox couple, yields a peak galvanic power density exceeding $0.6 \mathrm{~W} \mathrm{~cm}$ at $1.3 \mathrm{~A} \mathrm{~cm}^{2}$. Cycling of this quinone-bromide flow battery showed $>99$ per cent storage capacity retention per cycle. The organic anthraquinone species can be synthesized from inexpensive commodity chemicals ${ }^{8}$. This organic approach 
permits tuning of important properties such as the reduction potential and solubility by adding functional groups: for example, we demonstrate that the addition of two hydroxy groups to AQDS increases the open circuit potential of the cell by $11 \%$ and we describe a pathway for further increases in cell voltage. The use of $\pi$-aromatic redox-active organic molecules instead of redox-active metals represents a new and promising direction for realizing massive electrical energy storage at greatly reduced cost.

Solutions of AQDS in sulphuric acid (negative side) and $\mathrm{Br}_{2}$ in $\mathrm{HBr}$ (positive side) were pumped through a flow cell as shown schematically in Fig. 1a. The quinone-bromide flow battery (QBFB) was constructed using a Nafion 212 membrane sandwiched between Toray carbon paper electrodes (six stacked on each side) with no catalysts; it is similar to a cell described elsewhere (see figure 2 in ref. 7). We report the potential-current response (Fig. 1b) and the potential-power relationship (Fig. 1c and d) for various states of charge (SOCs; measured with respect to the quinone side of the cell). As the SOC increased from 10\% to $90 \%$, the open-circuit potential increased linearly from $0.69 \mathrm{~V}$ to $0.92 \mathrm{~V}$. In the galvanic direction, peak power densities were $0.246 \mathrm{~W} \mathrm{~cm}^{-2}$ and $0.600 \mathrm{~W} \mathrm{~cm}^{-2}$ at these same SOCs, respectively (Fig. 1c). In order to avoid significant water splitting in the electrolytic direction, we used a cutoff voltage of $1.5 \mathrm{~V}$, at which point the current densities observed at $10 \%$ and $90 \%$ SOCs were $-2.25 \mathrm{~A} \mathrm{~cm}^{-2}$ and $-0.95 \mathrm{~A} \mathrm{~cm}^{-2}$, respectively, with corresponding power densities of $-3.342 \mathrm{~W} \mathrm{~cm}^{-2}$ and $-1.414 \mathrm{~W} \mathrm{~cm}^{-2}$.

In Fig. 2 we report the results of initial cycling studies for this battery, to test for consistent performance over longer timescales. Fig. 2a shows cycling data at $\pm 0.2 \mathrm{~A} \mathrm{~cm}^{-2}$ using $50 \%$ of the total capacity of the battery. The cycles are highly reproducible and indicate that current efficiencies for the battery are around $95 \%$. Fig. 2 b shows constant-current cycling data, collected at $\pm 0.5 \mathrm{~A} \mathrm{~cm}^{-2}$, using voltage cut-offs of $0 \mathrm{~V}$ and $1.5 \mathrm{~V}$. These tests were done using the identical solutions used in the battery for Fig. 1b-d. The galvanic discharge capacity retention (that is, the number of coulombs extracted in one cycle divided by the number of coulombs extracted in the previous cycle) is above $99 \%$, indicating the battery is capable of operating with minimal capacity fade and suggesting that current efficiencies are actually closer to $99 \%$. Full characterization of the current efficiency will require slower cycling experiments and chemical characterization of the electrolyte solutions after extended cycling. 
In order to gain a better understanding of the quinone half-reaction on carbon, AQDS was subjected to half-cell electrochemical measurements. Cyclic voltammetry of a $1 \mathrm{mM}$ solution of AQDS in $1 \mathrm{M}$ sulphuric acid on a glassy carbon disk working electrode shows current peaks corresponding to reduction and oxidation of the anthraquinone species ${ }^{9-11}$ (Fig. 3d, solid trace). The peak separation of $34 \mathrm{mV}$ is close to the value of $59 \mathrm{mV} / \mathrm{n}$, where $n$ is the number of electrons involved, expected for a two-electron process. Rotation of this disk at a variety of rates yields mass-transport limited currents (Fig. 3a) from which the AQDS diffusion coefficient $\left(D=3.8(1) \times 10^{-6} \mathrm{~cm}^{2} \mathrm{~s}^{-1}\right)$ can be determined; throughout this paper, the numbers reported in parentheses indicate the standard deviation in the last reported digit. Koutecký-Levich analysis at low overpotentials (Fig. 3b) can be extrapolated to infinite rotation rate and fitted to the ButlerVolmer equation (Extended Data Fig. 3a) to give the kinetic reduction rate constant $k_{0}=7.2(5) \times 10^{-3} \mathrm{~cm} \mathrm{~s}^{-1}$. This rate constant is faster than that found for other species used in flow batteries such as $\mathrm{V}^{3+} / \mathrm{V}^{2+}, \mathrm{Br}_{2} / \mathrm{Br}^{-}$and $\mathrm{S}_{4}{ }^{2-} / \mathrm{S}_{2}{ }^{2-}$ (see table 2 in ref. 3 ). It implies that the voltage loss due to the rate of surface electrochemical reactions is negligible. The fast rate is apparently due to an outer-sphere two-electron reduction into the aromatic $\pi$ system requiring little reorganizational energy. The electrochemical reversibility of the two-electron redox reaction was confirmed by fitting the slope to the Butler-Volmer equation (Extended Data Fig. 3a), giving the transfer coefficient $\alpha=0.474(2)$, which is close to the value of 0.5 expected for an ideally reversible reaction. The Pourbaix diagram (Extended Data Fig. 4) confirms that a twoelectron, two-proton reduction occurs in acidic solution, and yields approximate $\mathrm{p} K_{\mathrm{a}}$ values of 7 and 11 for the reduced AQDS species ${ }^{11}$.

Functionalization of the anthraquinone backbone with electron-donating groups such as hydroxy can be expected lower the reduction potential of AQDS $\left(E^{0}\right)$, thereby raising the cell voltage $^{12}$. Hydroxy-substituted anthraquinones are synthesized through oxidation reactions that may be performed at minimal cost. They are also natural products that have been extracted for millennia from common sources such as rhubarb and could even provide a renewable source for future anthraquinone-based electrolyte solutions.

Quantum chemical calculations of un-substituted and hydroxy-substituted AQDS were performed to predict how substitution patterns would change both $E^{0}$ of the quinone/hydroquinone couples (Fig. 3c) and the solvation free energy $\left(G_{\text {solv }}^{0}\right)$ in aqueous solution 
(Extended Data Table 1). The addition of $-\mathrm{OH}$ groups is calculated to lower the $E^{0}$ by an average of $-50 \mathrm{mV}$ per $-\mathrm{OH}$ and provide a wide window for tuning $E^{0}$ by almost $0.6 \mathrm{~V}$. In addition, increasing numbers of hydroxy substituents are expected to raise the aqueous solubility due to hydrogen bonding.

In confirmation of the theory, the experimental reduction potential of 1,8-dihydroxy9,10-anthraquinone-2,7-disulphonic acid (DHAQDS) was found to be $118 \mathrm{mV}$ (versus the standard hydrogen electrode), which is very close to the $101 \mathrm{mV}$ calculated for this species (Fig. $3 \mathrm{c}$ and d). The experimental $E^{0}$ of DHAQDS was $95 \mathrm{mV}$ lower than AQDS, and would result in an 11\% increase in QBFB cell potential. DHAQDS was also found to have faster reduction kinetics $\left(k_{0}=1.56(5) \times 10^{-2} \mathrm{~cm} \mathrm{~s}^{-}{ }^{1}\right)$, possibly due to intramolecular hydrogen bonding of the $-\mathrm{OH}$ to the ketone (Extended Data Fig. 3b).

The organic approach liberates battery redox chemistry from the constraints of the limited number of elemental redox couples of the periodic table. Although quinones have been used previously in batteries using redox-active solids ${ }^{13-15}$, their incorporation into all-liquid flow batteries offers the following advantages over current flow-battery technologies. First, scalability: AQDS contains only the Earth-abundant atoms carbon, sulphur, hydrogen and oxygen, and can be inexpensively manufactured on large scales. Because some hydroxyanthraquinones are natural products, there is also the possibility that the electrolyte material can be renewably sourced. Second, kinetics: quinones undergo extremely rapid two-electron redox on simple, inexpensive carbon electrodes and do not require a costly precious metal catalyst. Furthermore, this electrode permits higher charging voltages by suppressing the parasitic watersplitting reactions. Third, stability: quinones should exhibit minimal membrane crossover due to their relatively large size and charge in aqueous solution as a sulphonate anion. Furthermore, although bromine crossover is a known issue in zinc-bromine, vanadium-bromine and hydrogenbromine cells, AQDS is stable to prolonged heating in concentrated $\mathrm{Br}_{2} / \mathrm{HBr}$ mixtures (Extended Data Figs 5 and 6), and the QBFB can be cycled in HBr electrolyte solutions (Extended Data Fig. 9). Fourth, solubility: AQDS has an aqueous solubility greater than $1 \mathrm{M}$ at $\mathrm{pH} 0$, and thus the quinone solution can be stored at relatively high energy density-volumetric and gravimetric energy densities exceed $50 \mathrm{~W} \mathrm{~h}^{-1}$ and $50 \mathrm{~W} \mathrm{~h} \mathrm{~kg}^{-1}$, respectively. Last, tunability: the reduction potential and solubility of AQDS can be further optimized by introduction of functional groups 
such as $-\mathrm{OH}$. Use of DHAQDS is expected to lead to an increase in cell potential, performance, and energy density.

These features lower the capital cost of storage chemicals per kilowatt hour, which sets a floor on the ultimate system cost per kilowatt hour at any scale. The precursor molecule anthracene is abundant in crude petroleum and is already oxidized on large scale to anthraquinone. Sulphonated anthraquinones are used on an industrial scale in wood pulp processing for paper $^{16}$, and they can be readily synthesized from the commodity chemicals anthraquinone and oleum ${ }^{8}$. In fact, a cyclic voltammogram of the crude sulphonation product of these two reagents is virtually identical to that of pure AQDS (Extended Data Fig. 8). Based on this simple electrolyte preparation that requires no further product separation, we estimate chemical costs of \$21 per kilowatt hour for AQDS and \$6 per kilowatt hour for bromine ${ }^{17}$ (see Methods for information on cost calculations). The QBFB offers major cost improvements over vanadium flow batteries with redox-active materials that cost $\$ 81$ per kilowatt hour (ref. 18). Optimization of engineering and operating parameters such as the flow field geometry, electrode design, membrane separator and temperature - which have not yet even begun — should lead to significant performance improvements in the future, as it has for vanadium flow batteries, which took many years to reach the power densities we report here ${ }^{6}$. The use of redox processes in $\pi$ aromatic organic molecules represents a new and promising direction for cost-effective, largescale energy storage.

\section{METHODS SUMMARY}

The QBFB comprised a mixture of commercially available and custom-made components. Pretreated $2 \mathrm{~cm}^{2}$, stacked (6×) Toray carbon paper electrodes (each of which is about $7.5 \mu \mathrm{m}$ uncompressed) were used on both sides of the cell. Nafion 212 (50 $\mu \mathrm{m}$ thick) was used as a proton-exchange membrane, and PTFE gasketing was used to seal the cell assembly. On the positive side of the cell, $120 \mathrm{ml}$ of $3 \mathrm{M} \mathrm{HBr}$ and $0.5 \mathrm{M} \mathrm{Br}_{2}$ were used as the electrolyte solution in the fully discharged state; on the negative side, $1 \mathrm{M}$ 2,7-AQDS in $1 \mathrm{M} \mathrm{H}_{2} \mathrm{SO}_{4}$ was used. AQDS disodium salt was flushed twice through a column containing Amberlyst $15 \mathrm{H}$ ionexchange resin to remove the sodium ions. Half-cell measurements were conducted using a $\mathrm{Ag} / \mathrm{AgCl}$ aqueous reference electrode (3 $\mathrm{M} \mathrm{KCl}$ filling solution), a Pt wire counter electrode, and a 3-mm-diameter glassy carbon disk electrode. For theoretical calculations, the total free energies 
of molecules were obtained from first-principles quantum chemical calculations within density functional theory at the level of generalized gradient approximation (GGA) using the PBE functional. Three-dimensional conformer structures for each quinone/hydroquinone molecule were generated using the ChemAxon suite with up to 25 generated conformers per molecule using the Dreiding force field. Generated conformers were used as input structures for the DFT geometry optimization employed for determining the formation energy, which in turn is used to evaluate the reduction potential. In the QBFB cost calculation, a price of $\$ 4.74$ per kilogram (eBioChem) was used for anthraquinone. To get the sulphonated form actually used here, anthraquinone must be reacted with oleum $\left(\mathrm{H}_{2} \mathrm{SO}_{4} / \mathrm{SO}_{3}\right)$, which adds a negligible cost at scale; this cost is not included here. The price of bromine was $\$ 1.76$ per kilogram, based on estimates from the US Geological Survey ${ }^{17}$. The cell voltage used to calculate costs here was $0.858 \mathrm{~V}$. Received 26 June; accepted 25 November 2013; doi:10.1038/nature12909.

1. Rugolo, J. \& Aziz, M. J. Electricity storage for intermittent renewable sources. Energy Environ. Sci. 5, 7151-7160 (2012).

2. $\quad$ Yang, Z. et al. Electrochemical energy storage for green grid. Chem. Rev. 111, 35773613 (2011).

3. Weber, A. Z. et al. Redox flow batteries: a review. J. Appl. Electrochem. 41, 1137-1164 (2011).

4. Leung, P. et al. Progress in redox flow batteries, remaining challenges and their applications in energy storage. RSC Adv. 2, 10125-10156 (2012).

5. Nguyen, T. \& Savinell, R. F. Flow batteries. Electrochem. Soc. Interface 19, 54-56 (2010).

6. Skyllas-Kazacos, M., Chakrabarti, M. H., Hajimolana, S. A., Mjalli, F. S. \& Saleem, M. Progress in flow battery research and development. J. Electrochem. Soc. 158, R55-R79 (2011).

7. Huskinson, B., Rugolo, J., Mondal, S. K. \& Aziz, M. J. A high power density, high efficiency hydrogen-chlorine regenerative fuel cell with a low precious metal content catalyst. Energy Environ. Sci. 5, 8690-8698 (2012).

8. Crossley, M. L. The separation of mono- $\beta, 2,6-$ and 2,7-sulfonic acids of anthraquinone. J. Am. Chem. Soc. 37, 2178-2181 (1915).

9. Conant, J. B., Kahn, H. M., Fieser, L. F. \& Kurtz, S. S. An electrochemical study of the reversible reduction of organic compounds. J. Am. Chem. Soc. 44, 1382-1396 (1922).

10. Kelsall, G. H. \& Thompson, I. Redox chemistry of $\mathrm{H}_{2} \mathrm{~S}$ oxidation by the British Gas Stretford process. Part III: Electrochemical behaviour of anthraquinone 2,7 disulphonate in alkaline electrolytes. J. Appl. Electrochem. 23, 296-307 (1993). 
11. Forster, R. J. \& O'Kelly, J. P. Protonation reactions of anthraquinone-2,7-disulphonic acid in solution and within monolayers. J. Electroanal. Chem. 498, 127-135 (2001).

12. Song, Y. \& Buettner, G. R. Thermodynamic and kinetic considerations for the reaction of semiquinone radicals to form superoxide and hydrogen peroxide. Free Radic. Biol. Med. 49, 919-962 (2010).

13. $\mathrm{Xu}, \mathrm{Y}$. et al. Novel organic redox flow batteries using soluble quinonoid compounds as positive materials. World Non-Grid-Connected Wind Power and Energy Conference 1-4 (2009). DOI: 10.1109/WNWEC.2009.5335870

14. Wang, W. et al. Anthraquinone with tailored structure for a nonaqueous metal-organic redox flow battery. Chem. Commun. 48, 6669-6671 (2012).

15. Yao, M. et al. High capacity organic positive-electrode material based on a benzoquinone derivative for use in rechargeable lithium batteries. J. Power Sources 195, 8336-8340 (2010).

16. Gordon, O. W., Plattner, E. \& Doppenberg, F. Production of pulp by the sodaanthraquinone process (SAP) with recovery of the cooking chemicals. US Patent No. $5,595,628(1997)$

17. US Geological Survey 2010 Minerals Yearbook: Bromine (2010); available at http://minerals.usgs.gov/minerals/pubs/commodity/bromine/myb1-2010-bromi.pdf.

18. US Geological Survey Vanadium Mineral Commodities Summary (2013); available at http://minerals.usgs.gov/minerals/pubs/commodity/vanadium/mcs-2013-vanad.pdf.

Acknowledgements This work was partially funded through US Department of Energy ARPA-E Award DEAR0000348 and partially funded through the Harvard School of Engineering and Applied Sciences. Theoretical work was funded in part through the Extreme Science and Engineering Discovery Environment (XSEDE), which is supported by National Science Foundation grant number OCI-1053575. B.H. was supported by an NSF Graduate Research Fellowship. S.E. performed work as part of the Fellowships for Young Energy Scientists programme of the Foundation for Fundamental Research on Matter (FOM), which is part of the Netherlands Organization for Scientific Research (NWO). We thank T. Betley, L. Hartle, R. Burton and R. Duncan for discussions.

Author Contributions B.H. and M.P.M contributed equally to this work. B.H. and M.P.M. designed and tested the battery, with direction from M.J.A. Both M.P.M and M.R.G. conducted electrochemistry experiments, with direction from M.J.A. M.P.M and C.J.G. synthesized chemicals with direction from R.G.G. Theoretical calculations were done by C.S. and S.E., with input from M. P. M. and R.G.G. and direction from A.A.-G. X.C. contributed NMR results. B.H., M.P.M., C.S., M.R.G, S.E., A.A.G., R.G.G. and M.J.A. all contributed to writing the manuscript.

Author Information Reprints and permissions information is available at www.nature.com/reprints. The authors declare competing financial interests: details are available in the online version of the paper. Readers are welcome to comment on the online version of the paper. Correspondence and requests for materials should be addressed to M.J.A. (maziz@harvard.edu), R.G.G (gordon@chemistry.harvard.edu) or A.A.-G (aspuru@chemistry.harvard.edu). 
a

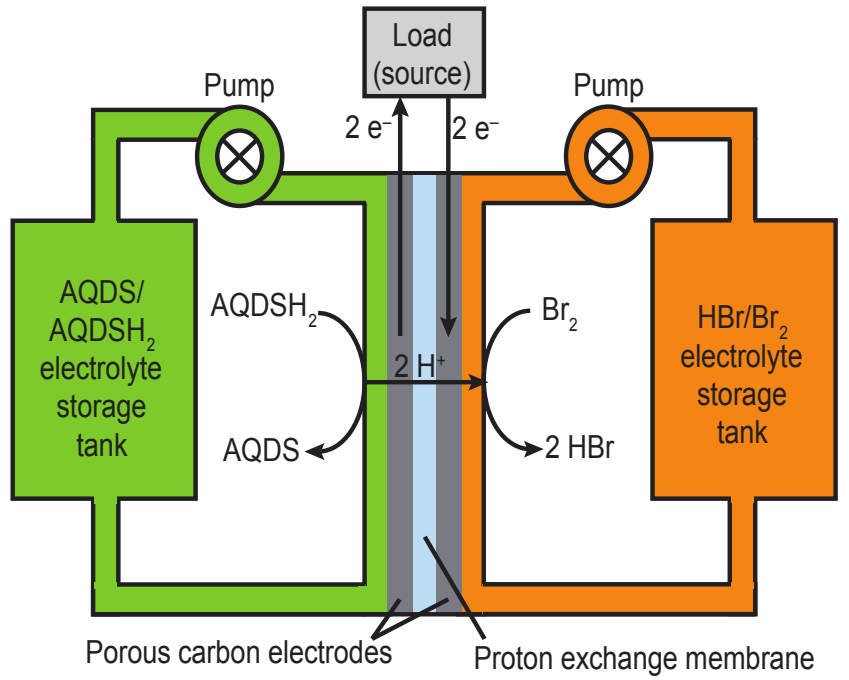

C

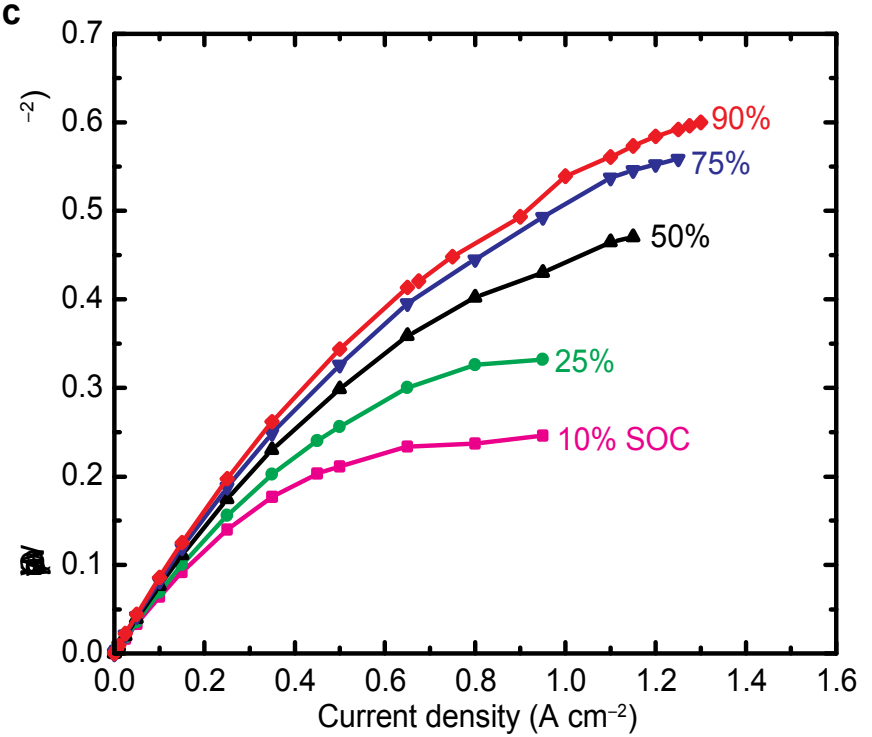

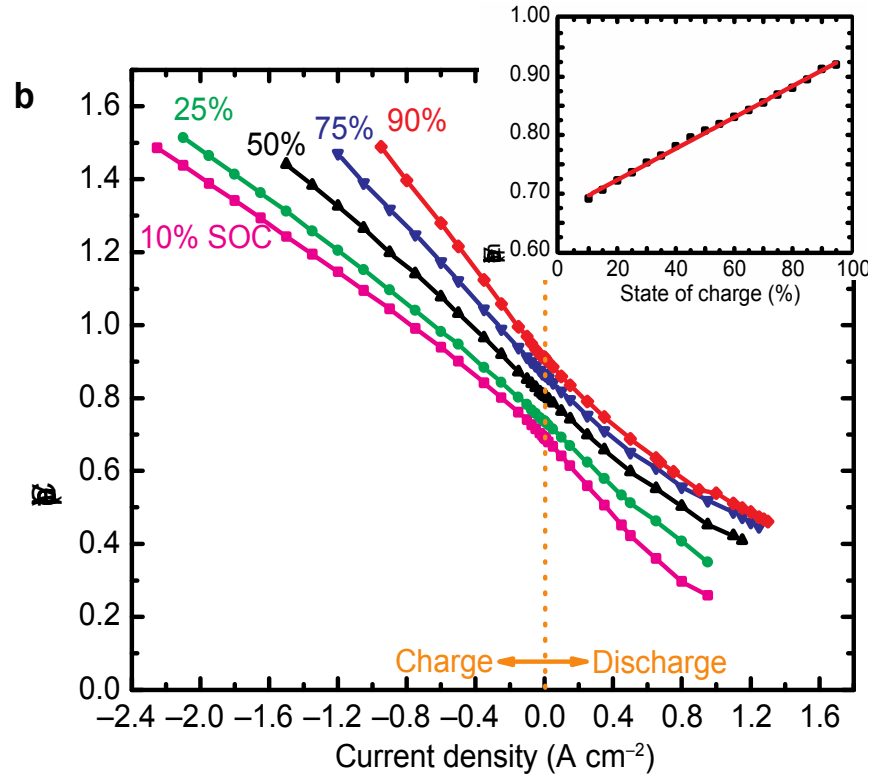

d

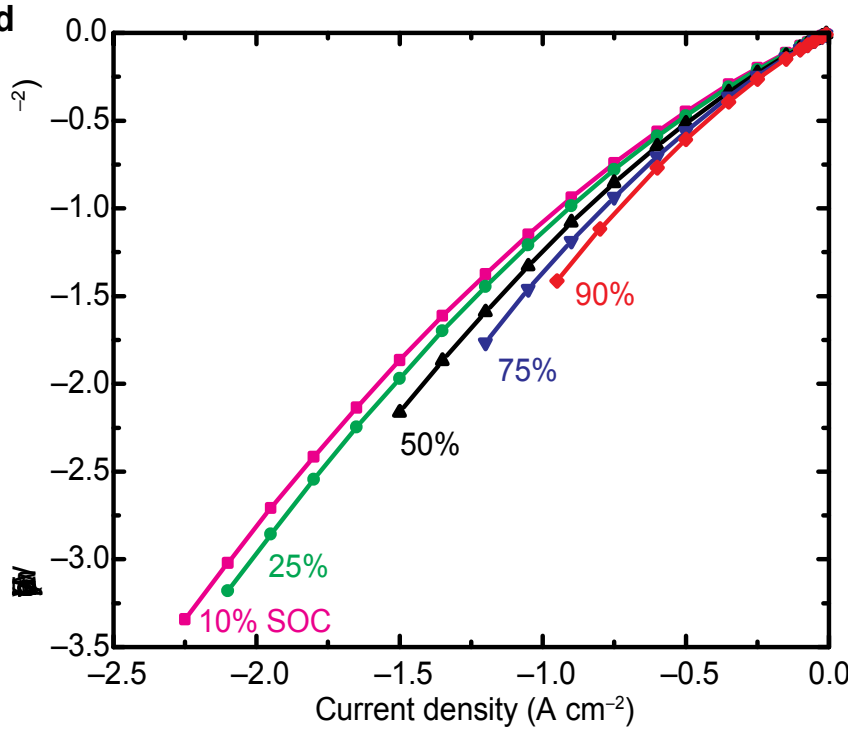

Figure 1 | Cell schematic and cell performance in galvanic and electrolytic modes. a, Cell schematic. Discharge mode is shown; the arrows are reversed for electrolytic/charge mode. $\mathrm{AQDSH}_{2}$ refers to the reduced form of AQDS. b, Cell potential versus current density at five different states of charge (SOCs; average of three runs); inset shows the cell open circuit potential versus SOC with best-fit line superimposed $\left(E_{\mathrm{eq}}=(0.00268 \times \mathrm{SOC})+0.670\right.$; $\left.R^{2}=0.998\right)$. c, Galvanic power density versus current density for the same SOCs. d, Electrolytic power density versus current density. All data here were collected at $40{ }^{\circ} \mathrm{C}$ using a $3 \mathrm{M}$ $\mathrm{HBr}+0.5 \mathrm{M} \mathrm{Br}_{2}$ solution on the positive side and a $1 \mathrm{M} \mathrm{AQDS}+1 \mathrm{M} \mathrm{H}_{2} \mathrm{SO}_{4}$ solution on the negative side. 

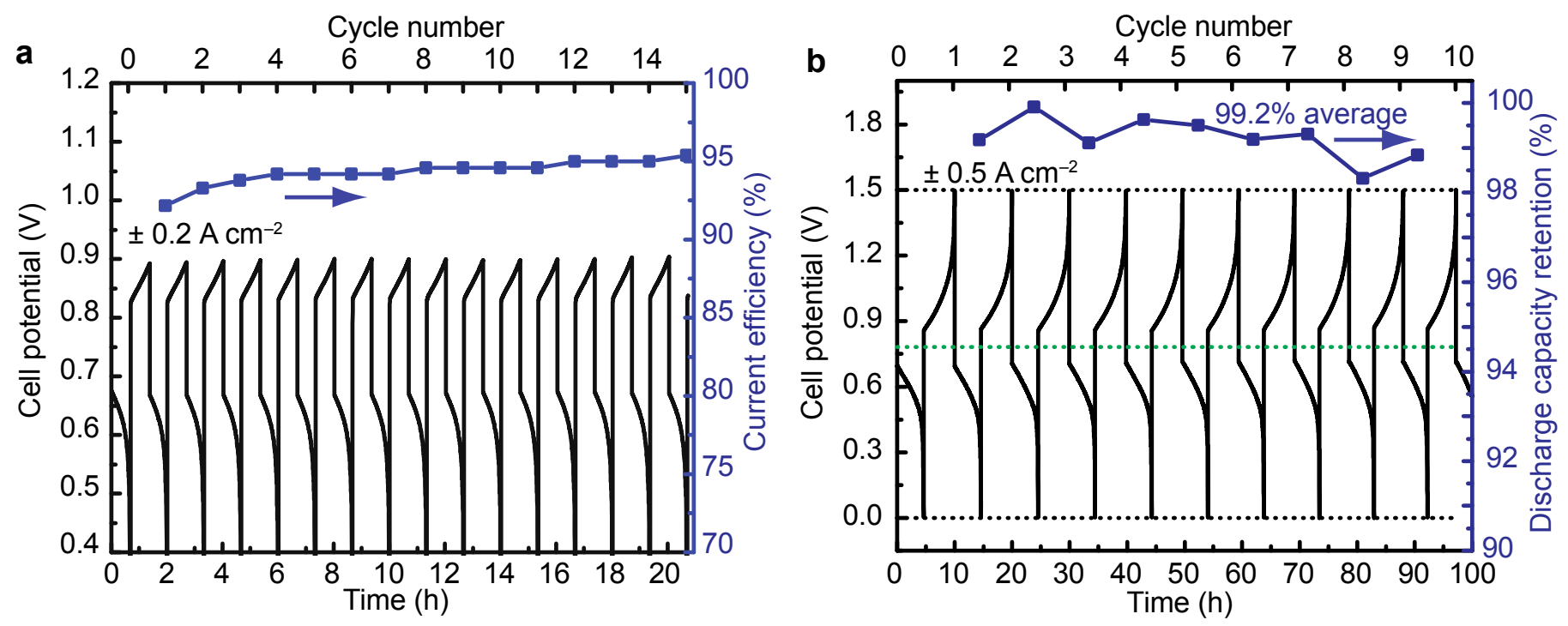

Figure 2 | Cell cycling behaviour. a, Constant-current cycling at $0.2 \mathrm{~A} \mathrm{~cm}^{-2}$ at $40{ }^{\circ} \mathrm{C}$ using a $2 \mathrm{M} \mathrm{HBr}+0.5 \mathrm{M} \mathrm{Br}_{2}$ solution on the positive side and a $0.1 \mathrm{M} \mathrm{AQDS}+2 \mathrm{M} \mathrm{H}_{2} \mathrm{SO}_{4}$ solution on the negative side; current efficiency is indicated for each complete cycle. $\mathbf{b}$, Constant-current cycling at $0.5 \mathrm{~A} \mathrm{~cm}^{-2}$ at $40{ }^{\circ} \mathrm{C}$ using a $3 \mathrm{M} \mathrm{HBr}+0.5 \mathrm{M} \mathrm{Br}_{2}$ solution on the positive side and a $1 \mathrm{M} \mathrm{AQDS}+1 \mathrm{M} \mathrm{H}_{2} \mathrm{SO}_{4}$ solution on the negative side (same solution used in Fig. 1); discharge capacity retention is indicated for each cycle. 

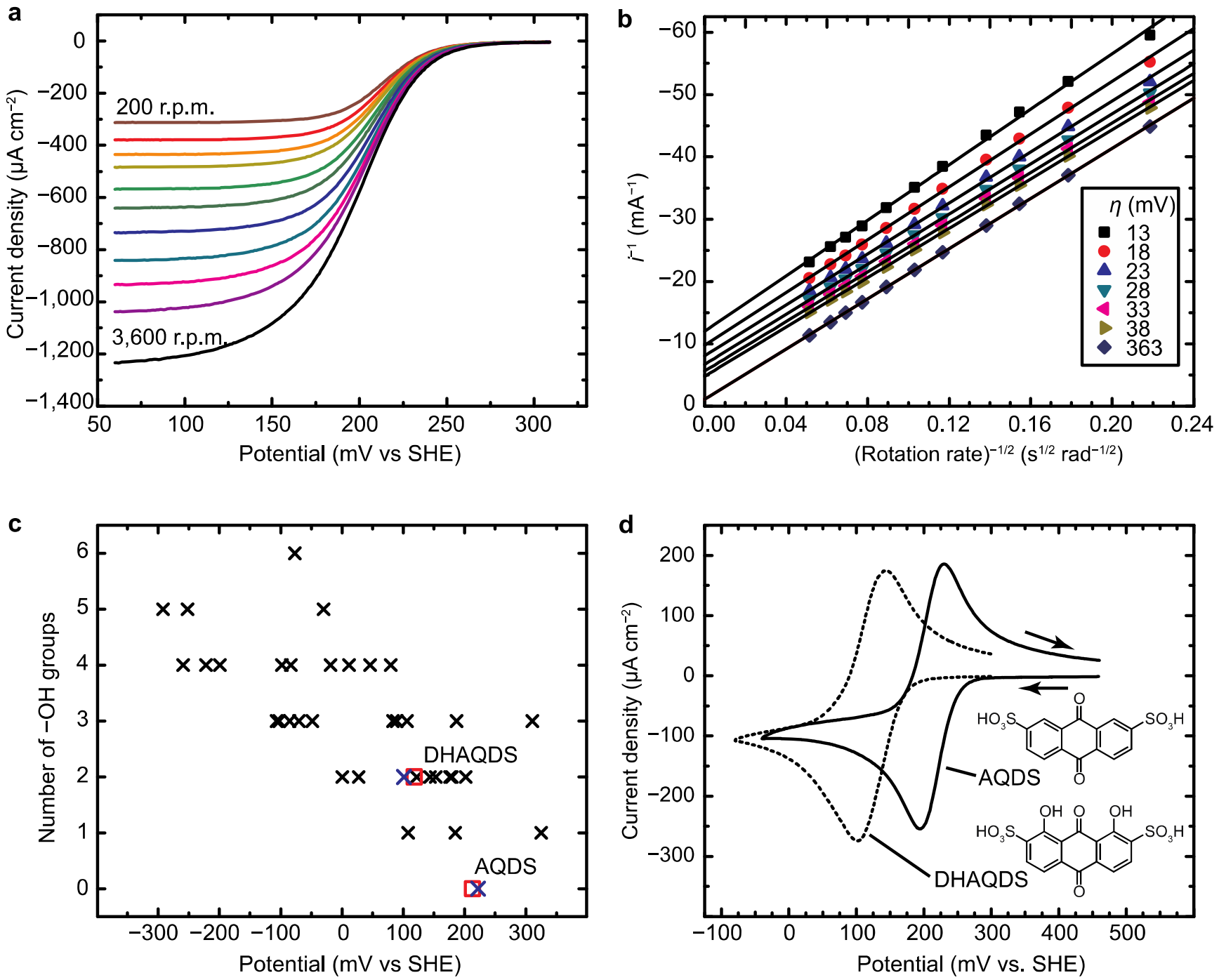

Figure 3 | Half-cell measurements and theory calculations. a, Rotating disk electrode (RDE) measurements of AQDS using a glassy carbon electrode in $1 \mathrm{M} \mathrm{H}_{2} \mathrm{SO}_{4}$ at 11 rotation rates ranging from 200 r.p.m. (red) to 3,600 r.p.m. (black). b, Koutecký-Levich plot (current ${ }^{-1}$ versus $^{-}$ rotation rate $^{-1 / 2}$ ) derived from a at seven different AQDS reduction overpotentials, $\eta$. c, Calculated reduction potentials of AQDS substituted with-OH groups (black), calculated AQDS and DHAQDS values (blue), and experimental values for AQDS and DHAQDS (red squares). d, Cyclic voltammogram of AQDS and DHAQDS (1 mM) in $1 \mathrm{M} \mathrm{H}_{2} \mathrm{SO}_{4}$ on a glassy carbon electrode $\left(\right.$ scan rate $\left.=25 \mathrm{mV} \mathrm{s}^{-1}\right)$. 


\section{ONLINE METHODS}

\section{Full cell measurements}

The QBFB comprised a mixture of commercially available and custom-made components. Circular endplates were machined out of solid aluminium. Current collectors were 3 inch $\times 3$ inch pyrolytic graphite blocks with interdigitated flow channels (channel width $=0.0625$ inch, channel depth $=0.08$ inch, landing between channels $=0.031$ inch, Fuel Cell Technologies). Pretreated $2 \mathrm{~cm}^{2}$, stacked (6×) Toray carbon paper electrodes (each of which is about $7.5 \mu \mathrm{m}$ uncompressed) were used on both sides of the cell. Pretreatment consisted of a 10 min sonication in isopropyl alcohol followed by a five hour soak in a hot $\left(50{ }^{\circ} \mathrm{C}\right)$ mixture of undiluted sulphuric and nitric acids in a 3:1 volumetric ratio. Nafion 212 (50 $\mu \mathrm{m}$ thick) was used as a proton-exchange membrane (PEM, Alfa Aesar), and PTFE gasketing was used to seal the cell assembly. Membrane pretreatment was done according to previously published protocols ${ }^{7}$. Six bolts (3/8", 16 threads per inch) torqued to $10.2 \mathrm{~N}$ m completed the cell assembly, and PTFE tubing was used to transport reactants and products into and out of the cell. The cell was kept on a hot plate and wrapped in a proportional-integral-derivative (PID)-controlled heating element for temperature control. On the positive side of the cell, $120 \mathrm{ml}$ of $3 \mathrm{M} \mathrm{HBr}$ and $0.5 \mathrm{M} \mathrm{Br}_{2} \mathrm{Were}$ used as the electrolyte solution in the fully discharged state; on the negative side, 1 M AQDS in $1 \mathrm{M} \mathrm{H}_{2} \mathrm{SO}_{4}$ was used. $\mathrm{HBr}$ was used on the negative side instead of $\mathrm{H}_{2} \mathrm{SO}_{4}$ for stability testing results displayed in Extended Data Fig. 9. State-of-charge calculations are based on the composition of the quinone side of the cell. 2,7-Anthraquinone disulphonate disodium salt $98 \%$ (TCI) was flushed twice through a column containing Amberlyst $15 \mathrm{H}$ ion-exchange resin to remove the sodium ions. Measurements shown here were done at $40{ }^{\circ} \mathrm{C}$. March centrifugal pumps were used to circulate the fluids at a rate of approximately $200 \mathrm{ml} \mathrm{min}^{-1}$. For characterization, several instruments were used: a CH Instruments 1100C potentiostat (which can be used up to $\pm 2 \mathrm{~A}$ ), a DC electronic load (Circuit Specialists) for galvanic discharge, a DC regulated power supply (Circuit Specialists) for electrolytic characterization, and a standard multimeter for independent voltage measurements. The cell was charged at $1.5 \mathrm{~V}$ until a fixed amount of charge ran through the cell. During this process, the electrolyte colours changed from orange to dark green (AQDS to $\left.\mathrm{AQDSH}{ }_{2}\right)$ and from colourless to red $\left(\mathrm{Br}^{-}\right.$to $\left.\mathrm{Br}_{2}\right)$. Periodically, the open circuit potential was measured, providing the data inset in Fig. 1b. Also, at various 
SOCs, potential-current behaviour was characterized using the equipment described above: a fixed current was drawn from the cell, and the voltage, once stabilized, was recorded (Fig. 1b). For the cycling data in Fig. $2 b$, the potentiostat was used for constant current $\left( \pm 0.5 \mathrm{~A} \mathrm{~cm}^{-2}\right)$ measurements with cut-off voltages of $0 \mathrm{~V}$ and 1.5 V. For the cycling data in Fig. 2a, a more dilute quinone solution ( $0.1 \mathrm{M}$ as opposed to $1 \mathrm{M}$ ) was used. Here, the half-cycle lengths were programmed to run at constant current for a fixed amount of time, provided the voltage cut-offs were not reached, so that half of the capacity of the battery was used in each cycle. The voltage cut-offs were never reached during charging, but were reached during discharge. Current efficiencies are evaluated by dividing the discharge time by the charge time of the previous halfcycle.

As shown in Fig. 2, current efficiency starts at about $92 \%$ and climbs to about $95 \%$ over $\sim 15$ standard cycles. Note that these measurements are done near viable operating current densities for a battery of this kind. Because of this, we believe this number places an upper bound on the irreversible losses in the cell. In any case, $95 \%$ is comparable to values seen for other battery systems. For example, ref. 19 reports vanadium bromide batteries with current efficiencies of 50-90\%, with large changes in current efficiency observed for varying membrane conditions. Our system will probably be less dependent on membrane conditions because we are storing energy in anions and neutral species as opposed to cations, which Nafion can conduct reasonably well.

In Fig. $2 \mathrm{~b}$ we illustrate the capacity retention of the battery (that is, the number of coulombs available for discharge at the $n$th cycle divided by that available for discharge at the $(n-1)$ th cycle) to be $99.2 \%$ on average, which is quite high and provides direct evidence that our irreversible losses are below $1 \%$. If we attribute all of this loss (the $0.78 \%$ capacity fade per cycle) to some loss of redox-active quinone, it would be equivalent to losing 0.0006634 moles of quinone per cycle. If we attribute all of the loss to bromine crossover (which would react with the hydroquinone and oxidize it back to quinone), this corresponds to a crossover current density of $1.785 \mathrm{~mA} \mathrm{~cm}^{-2}$, which is within the range of the widely varying crossover values reported in the literature ${ }^{20}$. Note that these crossover numbers can be very sensitive to membrane pretreatment conditions. It is also important to mention that, in order to determine very accurate current efficiencies, detailed chemical analyses of the electrolyte are necessary. 


\section{Half-cell measurements}

These were conducted using a BASi Epsilon EC potentiostat, a BASi Ag/AgCl aqueous reference electrode (RE-5B, $3 \mathrm{M} \mathrm{KCl}$ filling solution) and a Pt wire counter electrode. Rotating disk electrode (RDE) measurements were conducted using a BASi RDE (RDE-2) and a $3 \mathrm{~mm}$ diameter glassy carbon disk electrode. Electrode potentials were converted to the standard hydrogen electrode $(\mathrm{SHE})$ scale using $E(\mathrm{SHE})=E(\mathrm{Ag} / \mathrm{AgCl})+0.210 \mathrm{~V}$, where $E(\mathrm{SHE})$ is the potential versus $\mathrm{SHE}$ and $\mathrm{E}(\mathrm{Ag} / \mathrm{AgCl})$ is the measured potential versus $\mathrm{Ag} / \mathrm{AgCl}$. 2,7Anthraquinone disulphonate disodium salt 98\% was purchased from TCI and used as received. 1,8-Dihydroxy-anthraquinone-2,7-disulphonic acid was made according to the literature procedure ${ }^{21}$. The electrolyte solution was sulphuric acid (ACS, Sigma) in deionized $\mathrm{H}_{2} \mathrm{O}$ $\left(18.2 \mathrm{M} \Omega \mathrm{cm}\right.$, Millipore). The Pourbaix diagram (plot of $E^{0}$ versus $\mathrm{pH}$ ) shown in Extended Data Fig. 4, was constructed using aqueous $1 \mathrm{mM}$ solutions of AQDS in $\mathrm{pH}$ buffers using the following chemicals: sulphuric acid (1 M, pH 0), $\mathrm{HSO}_{4}{ }^{-} / \mathrm{SO}_{4}{ }^{2-}(0.1 \mathrm{M}, \mathrm{pH} 1-2), \mathrm{AcOH} / \mathrm{AcO}^{-}$ (0.1 M, pH 2.65-5), $\mathrm{H}_{2} \mathrm{PO}_{4}{ }^{-} / \mathrm{HPO}_{4}{ }^{2-}(0.1 \mathrm{M}, \mathrm{pH} 5.3-8), \mathrm{HPO}_{4}{ }^{2-} / \mathrm{PO}_{4}{ }^{3-}(0.1 \mathrm{M}, \mathrm{pH} 9.28-11.52)$, and $\mathrm{KOH}(0.1 \mathrm{M}, \mathrm{pH} 13)$. The $\mathrm{pH}$ of each solution was adjusted with $1 \mathrm{M} \mathrm{H}_{2} \mathrm{SO}_{4}$ or $0.1 \mathrm{M} \mathrm{KOH}$ solutions and measured with an Oakton $\mathrm{pH} 11$ Series $\mathrm{pH}$ meter (Eutech Instruments).

\section{RDE studies}

All RDE data represent an average of three runs. Error bars in Extended Data Figs 2 and 3 indicate standard deviations. Before each run, the glassy carbon disk working electrode was polished to a mirror shine with $0.05 \mu \mathrm{m}$ alumina and rinsed with deionized water until a cyclic voltammogram of a solution of $1 \mathrm{mM}$ AQDS in $1 \mathrm{M} \mathrm{H}_{2} \mathrm{SO}_{4}$ showed anodic and cathodic peak voltage separation of 34 to $35 \mathrm{mV}$ ( $39 \mathrm{mV}$ for DHAQDS) at a sweep rate of $25 \mathrm{mV} \mathrm{s}^{-1}$. The electrode was then rotated at 200,300, 400, 500, 700, 900, 1,200, 1,600, 2,000, 2,500 and 3,600 r.p.m. while the voltage was linearly swept from 310 to $60 \mathrm{mV}$ (250 to -100 for DHAQDS) at $10 \mathrm{mV} \mathrm{s}^{-1}$ (Extended Data Fig. 1). The currents measured at $60 \mathrm{mV}$ (-100 for DHAQDS) (that is, the diffusion limited current density) versus the square root of the rotation rate $(\omega)$ is plotted in Extended Data Fig. 2. The data were fitted with a straight line, with the slope defined by the Levich equation as $0.620 n F A C_{\mathrm{O}} D^{2 / 3} v^{-1 / 6}$, where $n=2$, Faraday's constant $F=96,485 \mathrm{C} \mathrm{mol}^{-1}$, electrode area $A=0.0707 \mathrm{~cm}^{2}$, AQDS concentration $C_{\mathrm{O}}=10^{-6} \mathrm{~mol} \mathrm{~cm}^{-3}$, kinematic viscosity $v=0.01 \mathrm{~cm}^{2} \mathrm{~s}^{-1}$. This gives $D$ values of $3.8(1) \times 10^{-6} \mathrm{~cm}^{2} \mathrm{~s}^{-1}$ for AQDS and 
$3.19(7) \times 10^{-6} \mathrm{~cm}^{2} \mathrm{~s}^{-1}$ for DHAQDS. The reciprocal of the current at overpotentials of 13,18 , $23,28,33,38$ and $363 \mathrm{mV}$ was plotted versus the reciprocal of the square root of the rotation rate (Fig. $3 \mathrm{~b}$ and Extended Data Fig. 2). The data for each potential were fitted with a straight line; the intercept gives the reciprocal of $i_{\mathrm{K}}$, the current in the absence of mass transport limitations (the extrapolation to infinite rotation rate). A plot of $\log _{10}\left(i_{\mathrm{K}}\right)$ versus overpotential was linearly fitted with a slope of $62 \mathrm{mV}$ (AQDS) and $68 \mathrm{mV}$ (DHAQDS) defined by the Butler-Volmer equation as 2.3 $\alpha R T / n F$ (Extended Data Fig. 3), where $R$ is the universal gas constant, $T$ is temperature in Kelvin, and $\alpha$ is the charge transfer coefficient. This gives $\alpha=0.474(2)$ for AQDS and 0.43(1) for DHAQDS. The $x$-intercept gives the log of the exchange current $i_{0}$, which is equal to $F A C_{\mathrm{O}} k_{0}$, and gives $k_{0}=7.2(5) \times 10^{-3} \mathrm{~cm} \mathrm{~s}^{-1}$ for AQDS and $1.56(5) \times 10^{-2} \mathrm{~cm} \mathrm{~s}^{-1}$ for DHAQDS.

\section{Stability studies}

AQDS (50 mg) was dissolved in $0.4 \mathrm{ml}$ of $\mathrm{D}_{2} \mathrm{O}$, and treated with $100 \mu \mathrm{lof} \mathrm{Br}_{2}$. The ${ }^{1} \mathrm{H}$ and ${ }^{13} \mathrm{C}$ NMR spectra (Extended Data Figs 5a, b and 6a, b) were unchanged from the starting material after standing for $20 \mathrm{~h}$ at $25^{\circ} \mathrm{C}$. AQDS $(50 \mathrm{mg})$ was then treated with $1 \mathrm{ml}$ of $2 \mathrm{M} \mathrm{HBr}$ and $100 \mu \mathrm{l}$ of $\mathrm{Br}_{2}$. The reaction was heated to $100^{\circ} \mathrm{C}$ for $48 \mathrm{~h}$ and evaporated to dryness at that temperature. The resulting solid was fully dissolved in $\mathrm{D}_{2} \mathrm{O}$ giving unchanged ${ }^{1} \mathrm{H}$ and ${ }^{13} \mathrm{C}$ NMR (Extended Data Figs 5c and 6c); however the ${ }^{1} \mathrm{H}$ NMR reference was shifted due to residual acid. These results imply that bromine crossover will not lead to irreversible destruction of AQDS.

\section{Sulphonation of anthraquinone and electrochemical study}

9,10-Anthraquinone was treated with $\mathrm{H}_{2} \mathrm{SO}_{4}\left(20 \% \mathrm{SO}_{3}\right)$ at $170{ }^{\circ} \mathrm{C}$ for $2 \mathrm{~h}$ according to a literature procedure ${ }^{8}$. The resulting red solution, containing roughly $37 \%$ AQDS, $60 \% 9$, 10 anthraquinone-2,6-disulphonic acid and 3\% 9,10-anthraquinone-2-sulphonic acid, was diluted and filtered. A portion of this solution was further diluted with $1 \mathrm{M} \mathrm{H}_{2} \mathrm{SO}_{4}$ to $\sim 1 \mathrm{mM}$ total anthraquinone concentration. The cyclic voltammogram (Extended Data Fig. 8) is similar to that of pure AQDS, though the anodic/cathodic peak current density is broadened due to the presence of the multiple sulphonic acid isomers.

\section{Theory and methods}

We used a fast and robust theoretical approach to determine the $E^{0}$ of quinone/hydroquinone couples in aqueous solutions. We employed an empirical linear correlation of $\Delta H_{\mathrm{f}}$, the heat of 
formation of hydroquinone at $0 \mathrm{~K}$ from the quinone and hydrogen gas, to the measured $E^{0}$ values $^{22}$. Following the treatment of ref. 22 , the linear correlation is described as $\Delta G=-n F E^{0}$, where $\Delta G$ is the difference in total free energy between quinone and hydroquinone, $n$ is the number of electrons involved in the reaction, and $F$ is the Faraday constant. The entropy contributions to the total free energies of reaction have been neglected because the entropies of reduction of quinones are found to be very similar ${ }^{22,23}$, and the $E^{0}$ of the oxidation-reduction system is linearly expressed as $(-n F)^{-1} \Delta H_{\mathrm{f}}+b$, where $b$ is a constant. It was also assumed that the reduction of quinones takes place in a single-step reaction involving a two-electron twoproton process ${ }^{9,24}$. The total free energies of molecules were obtained from first-principles quantum chemical calculations within density functional theory (DFT) at the level of generalized gradient approximation (GGA) using the PBE functional ${ }^{25}$. The projector augmented wave (PAW) technique and a plane-wave basis set ${ }^{26,27}$ as implemented in $\mathrm{VASP}^{28,29}$ were employed. The kinetic energy cut-off for the plane-wave basis was set at $500 \mathrm{eV}$, which was sufficient to converge the total energies on a scale of $1 \mathrm{meV}$ per atom. To obtain the ground-state structures of molecules in the gas phase, we considered multiple initial configurations for each molecule and optimized them in a cubic box of $25 \AA$ using $\Gamma$-point sampling. The geometries were optimized without any symmetry constraints using the conjugate gradient (CG) algorithm, and the convergence was assumed to be complete when the total remaining forces on the atoms were less than $0.01 \mathrm{eV} \AA^{-1}$. [

The search for conformational preference through theoretical calculations for each hydroxylated quinone is crucial because of the significant effects of intramolecular hydrogen bonds on the total free energies of the molecules ${ }^{30}$. Three-dimensional conformer structures for each quinone/hydroquinone molecule were generated using the ChemAxon suite (Marvin 6.1.0 by ChemAxon, http://www.chemaxon.com) with up to 25 conformers generated per molecule using the Dreiding force field ${ }^{31}$. The conformers generated were used as input structures for the DFT geometry optimization employed for determining $\Delta H_{\mathrm{f}}$, which in turn is used to estimate $E^{0}$ and $G_{\text {solv }}^{0}$.

In order to calculate the $E^{0}$ of the hydroxy-substituted AQDS molecules (Fig 3c), the correlation between $\Delta H_{\mathrm{f}}$ and $E^{0}$ was calibrated from experimental data of six well-characterized quinones $^{32}$. Specifically, we employed the experimental values of the aqueous $E^{0}$ and computed 
$\Delta H_{\mathrm{f}}$ of 1,2-benzoquinone, 1,4-benzoquione, 1,2-naphthoquinone, 1,4-naphthoquinone, 9,10anthraquinone, and 9,10-phenanthrene ${ }^{33}$. The training set ensures that the calibration plot addresses most classes and aspects of quinones, including two quinones each from 1-ring (benzoquinone), 2-ring (naphthoquinone) and 3-ring (anthraquinone and phenanthrene) structures. In addition, the experimental values of $E^{0}$ of the training set spanned from $0.09 \mathrm{~V}$ (9,10-anthraquinone) to $0.83 \mathrm{~V}$ (1,2-benzoquinone), providing a wide range for $E^{0}$ (Extended Data Fig. 7). The linear calibration plot for $E^{0}$ yields an $R^{2}=0.97$ between the calculated $\Delta H_{\mathrm{f}}$ and $E^{0}$ (Extended Data Fig. 7).

The $G_{\text {solv }}^{0}$ values of the quinones in water were calculated using the Jaguar 8.0 program in the Schrödinger suite 2012 (Jaguar, version 8.0, Schrödinger). The standard Poisson-Boltzmann solver was employed ${ }^{34,35}$. In this model, a layer of charges on the molecular surface represents the solvent. $G_{\text {solv }}^{0}$ was calculated as the difference between the total energy of the solvated structure and the total energy of the molecule in vacuum. A more negative value for $G_{\text {solv }}^{0}$ corresponds to a quinone that is likely to have a higher aqueous solubility. An absolute prediction of the solubility is not readily available, as the accurate prediction of the most stable forms of molecular crystal structures with DFT remains an open problem ${ }^{36}$.

\section{Cost calculations}

These were done using the following formula: $C=\left(3.6 \times 10^{3}\right) \times(P M) /(n F E)$, where $C$ is the cost in US dollars of the compound per kilowatt hour, $P$ is the cost in US dollars per kilogram, $M$ is the molecular mass of the compound, $F$ is Faraday's constant $\left(96,485 \mathrm{C} \mathrm{mol}^{-1}\right), n$ is the number of moles of electrons transferred per mole of storage compound (two for the QBFB), and $E$ is the open-circuit voltage $(\mathrm{V})$ of the storage device. In calculating the price for the anthraquinonebromine battery, a price of $\$ 4.74$ per kilogram (eBioChem) was used for anthraquinone (note that, in order to get the sulphonated form actually used here, anthraquinone must be reacted with oleum $\left(\mathrm{H}_{2} \mathrm{SO}_{4} / \mathrm{SO}_{3}\right)$, which adds a negligible cost at scale; this cost is not included here). The price of bromine was $\$ 1.76$ per kilogram, based on estimates from the US Geological Survey ${ }^{17}$. The cell voltage used to calculate costs here was $0.858 \mathrm{~V}$. For vanadium, costs were calculated from USGS prices from $2011^{18}$ of vanadium pentoxide at $\$ 14.37$ per kilogram, and the cell voltage used was 1.2 V. Balance-of-system costs have not been estimated because the technology is too immature. 
19. Skyllas-Kazacos, M., Milne, N. A. \& Kazacos, G. C. Membrane properties and behavior in the Generation 2 vanadium bromide redox flow batteries. Materials Forum 32, 72-77 (2008).

20. Yeo, R. S. \& McBreen, J. Transport properties of Nafion membranes in electrochemically regenerative hydrogen/halogen cells. J. Electrochem. Soc. 126, 16821687 (1979).

21. Haase, J., Baudys, J., Obruba, K. \& Panek, J. Dihydroxyanthraquinone disulfonic acids. CS Patent No. 148,977 (1973).

22. Dewar, M. J. S. \& Trinajstic, N. Ground states of conjugated molecules-XIV: Redox potentials of quinones. Tetrahedron 25, 4529-4534 (1969).

23. Pullman, B. \& Pullman, A. Quantum Biochemistry 475 (Interscience, 1963).

24. Guin, P. S., Das, S. \& Mandal, P. C. Electrochemical reduction of quinones in different media: a review. Int. J. Electrochem. 816202 (2011).

25. Perdew, J. P., Burke, K. \& Ernzerhof, M. Generalized gradient approximation made simple. Phys. Rev. Lett. 77, 3865-3868 (1996).

26. Blöchl, P. E. Projector augmented-wave method. Phys. Rev. B 50, 17953-17979 (1994).

27. Kresse, G. \& Joubert, D. From ultrasoft pseudopotentials to the projector augmentedwave method. Phys. Rev. B 59, 1758-1775 (1999).

28. Kresse, G. \& Hafner, J. Ab initio molecular dynamics for liquid metals. Phys. Rev. B 47, 558-561 (1993).

29. Kresse, G. \& Furthmuller, J. Efficient iterative schemes for ab initio total-energy calculations using a plane-wave basis set. Phys. Rev. B 54, 11169-11186 (1996).

30. Qu, R., Liu, H., Feng, M., Yang, X. \& Wang, Z. Investigation on intramolecular hydrogen bond and some thermodynamic properties of polyhydroxylated anthraquinones. J. Chem. Eng. Data 57, 2442-2455 (2012).

31. Mayo, S. L., Olafson, B. D. \& Goddard, W. A. III Dreiding: A generic force field for molecular simulations. J. Phys. Chem. 94, 8897-8909 (1990).

32. Wang, J. \& Hou, T. Recent advances on aqueous solubility prediction. Comb. Chem. High Throughput Screen. 14, 328-338 (2011).

33. Johnsson Wass, J. R. T., Ahlberg, E., Panas, I. \& Schiffrin, D. J. Quantum chemical modeling of the reduction of quinones. J. Phys. Chem. A 110, 2005-2020 (2006).

34. Tannor, D. J. et al. Accurate first principles calculation of molecular charge distributions and solvation energies from ab initio quantum mechanics and continuum dielectric theory. J. Am. Chem. Soc. 116, 11875-11882 (1994).

35. Marten, B. et al. New model for calculation of solvation free energies: correction of self-consistent reaction field continuum dielectric theory for short-range hydrogenbonding effects. J. Phys. Chem. 100, 11775-11788 (1996).

36. Hongo, K., Watson, M. A., Sánchez-Carrera, R. S., Iitaka, T. \& Aspuru-Guzik, A. Failure of conventional density functionals for the prediction of molecular crystal 
polymorphism: a quantum Monte Carlo study. J. Phys. Chem. Lett. 1, 1789-1794 (2010). 


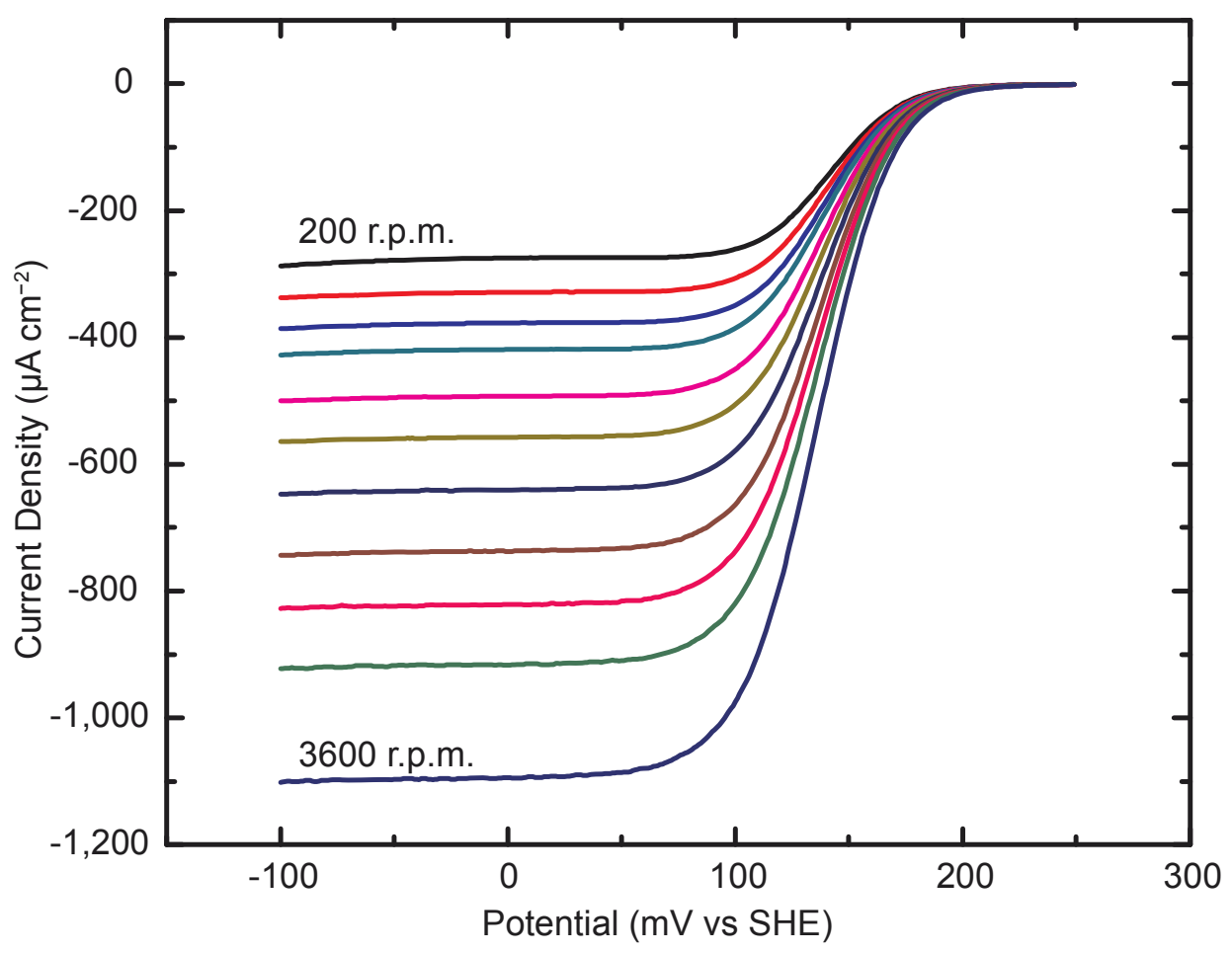

Extended Data Figure 1 | Plot of potential versus current density at different rotation rates of the RDE. The solution is $1 \mathrm{mM}$ DHAQDS ( $1 \mathrm{mM}$ in $\left.1 \mathrm{M} \mathrm{H}_{2} \mathrm{SO}_{4}\right)$, using a rotating disk electrode (RDE) of glassy carbon. Rotation rates are 200, 300, 400, 500, 700, 900, 1,200, 1,600, 2,000, 2,500 and 3,600 r.p.m. 

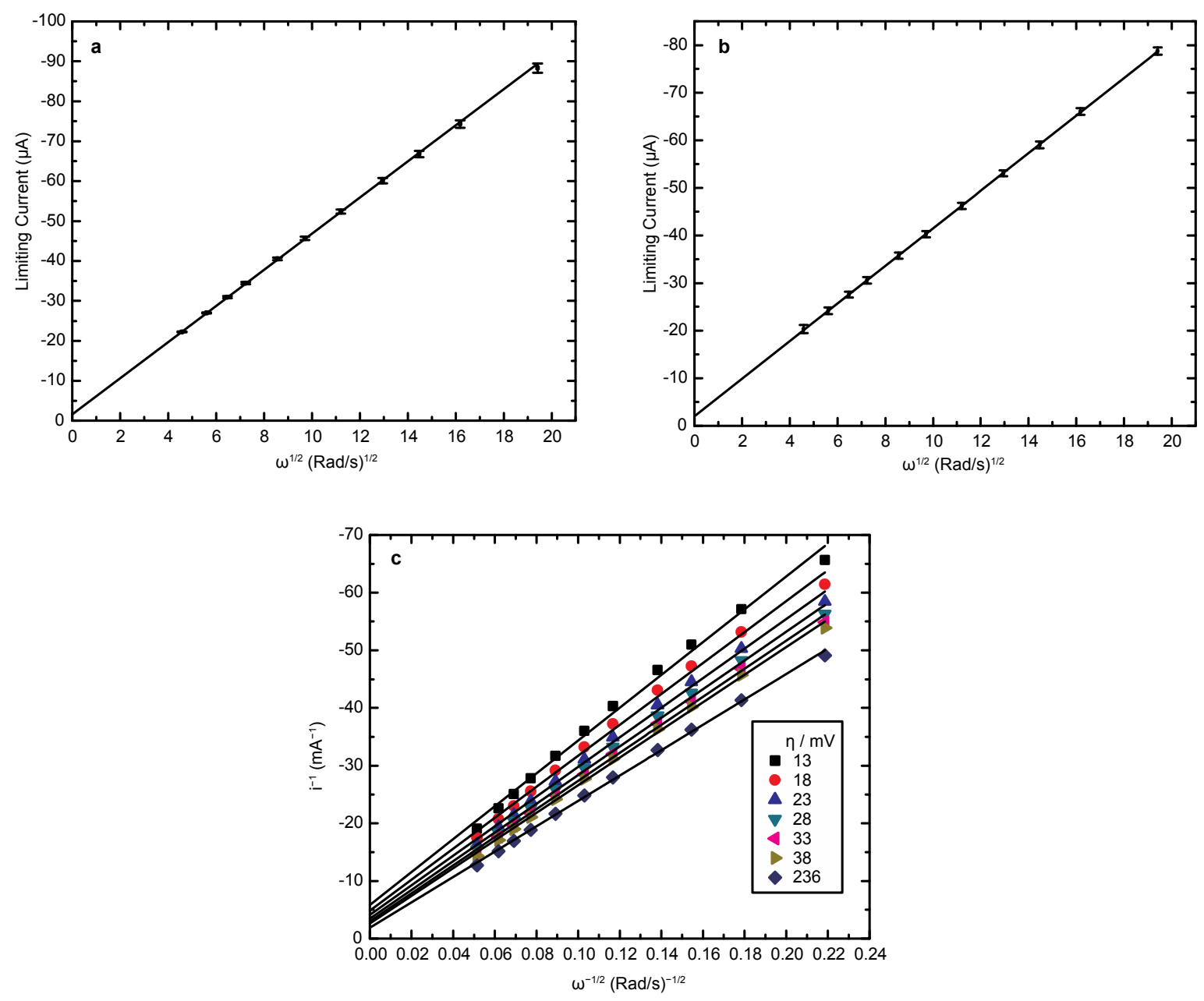

Extended Data Figure 2 | Levich and Koutecký-Levich plots obtained using the RDE. a, Levich plot (limiting current versus square root of rotation rate $\omega$ ) of $1 \mathrm{mM}$ AQDS in $1 \mathrm{M}$ $\mathrm{H}_{2} \mathrm{SO}_{4}$. (the fitted line has a slope of 4.53(2) $\mu \mathrm{A} \mathrm{s}^{1 / 2} \mathrm{rad}^{-1 / 2}$, giving $D=3.8(1) \times 10^{-6} \mathrm{~cm}^{2} \mathrm{~s}^{-1}$ ). Data are an average of three runs; error bars indicate the standard deviation. $\mathbf{b}$, As $\mathbf{a}$ but for DHAQDS in $1 \mathrm{M} \mathrm{H}_{2} \mathrm{SO}_{4}$ (slope of 3.94(6) $\mu \mathrm{A} \mathrm{s}^{1 / 2} \mathrm{rad}^{-1 / 2}$ gives $D=3.19(7) \times 10^{-6} \mathrm{~cm}^{2} \mathrm{~s}^{-1}$ ). c, Koutecký-Levich plot $\left(i^{-1}\right.$ versus $\omega^{-1 / 2}$ ) of $1 \mathrm{mM} \mathrm{DHAQDS}$ in $1 \mathrm{M} \mathrm{H}_{2} \mathrm{SO}_{4}$. The current response $i$ is shown for seven different AQDS reduction overpotentials $\eta$. 

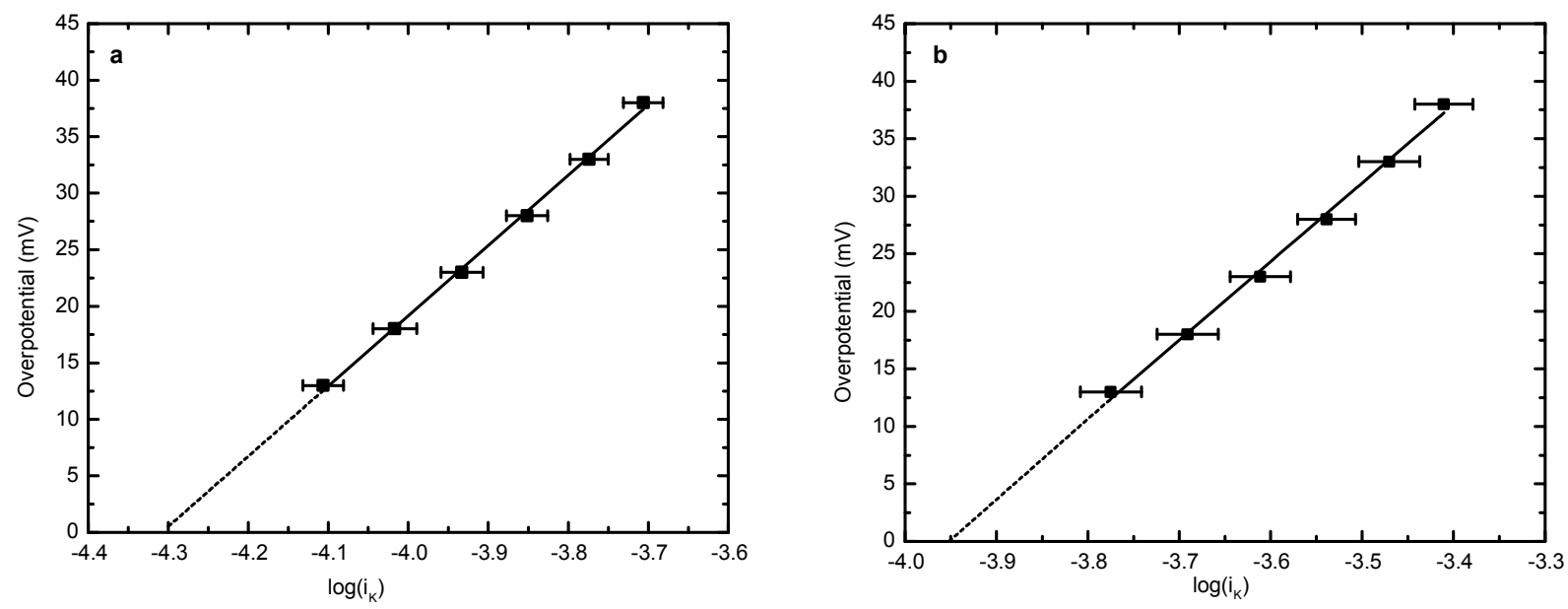

Extended Data Figure 3 | Fit of Butler-Volmer equation. Constructed using the current response in the absence of mass-transport at low AQDS reduction overpotentials; $i_{\mathrm{K}}$ is the current extrapolated from the zero-intercept of Fig. 3b and Extended Data Fig. 2c (infinite rotation rate). Data are an average of three runs; error bars indicate the standard deviation. a, AQDS: best-fit line has the equation $y=62(x+4.32)$. This yields $\alpha=0.474(2)$ and $k_{0}=7.2(5) \times 10^{-3} \mathrm{~cm} \mathrm{~s}^{-1}$. b, DHAQDS: best-fit line is the function $y=68(x+3.95)$. This yields $\alpha=0.43(1)$ and $k_{0}=1.56(5) \times 10^{-2} \mathrm{~cm} \mathrm{~s}^{-1}$. 


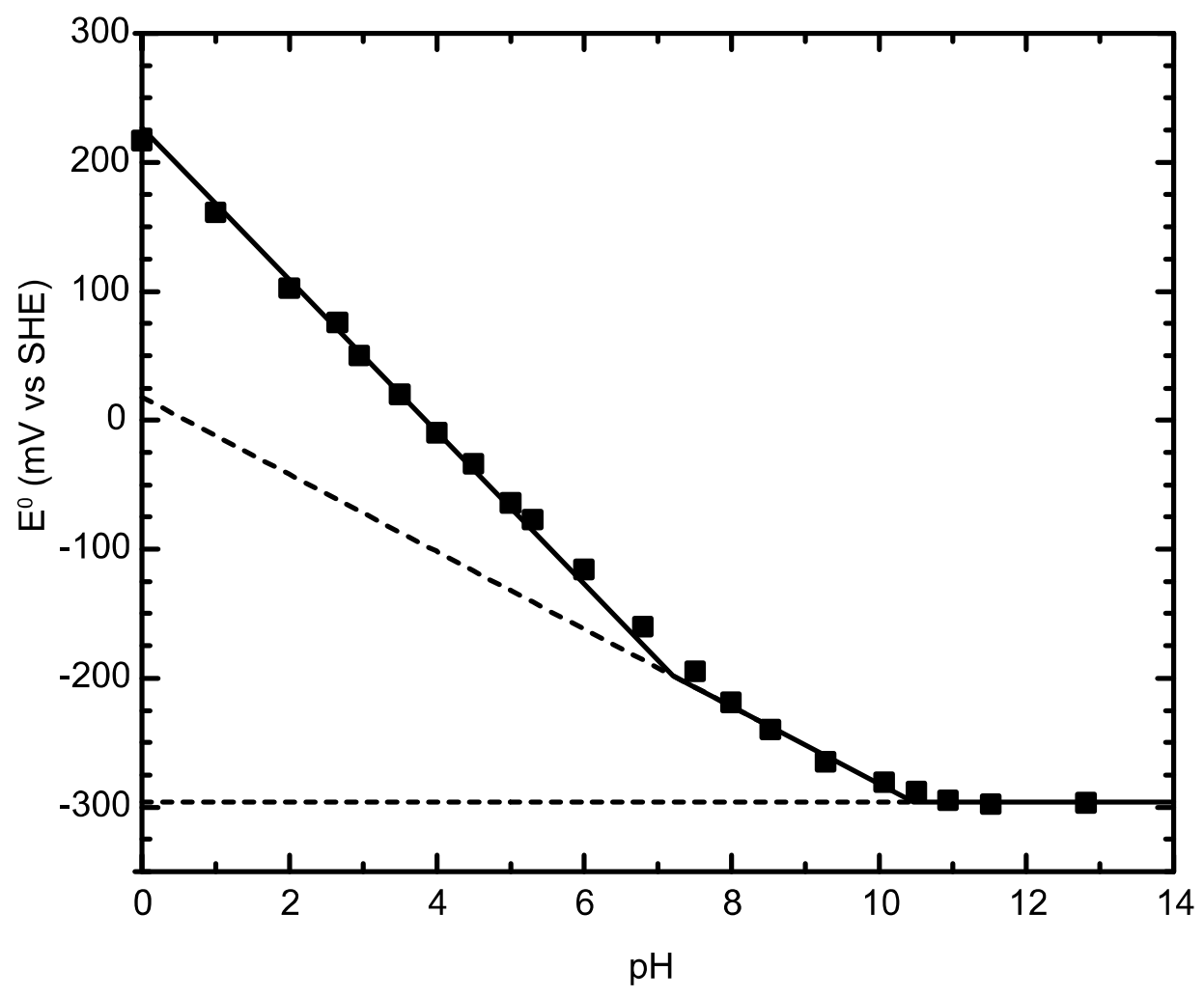

Extended Data Figure $4 \mid$ Pourbaix diagram $\left(\mathbf{E}^{\mathbf{0}}\right.$ vs. pH) of AQDS. Data are fit to three solid lines indicating slopes of $-59 \mathrm{mV} \mathrm{pH}^{-1},-30 \mathrm{mV} \mathrm{pH}^{-1}$ and $0 \mathrm{mV} \mathrm{pH}^{-1}$, corresponding to two-, one- and zero-proton processes, respectively. Dashed lines linearly extrapolate the one- and zeroproton processes to give $E^{0}$ values of $18 \mathrm{mV}\left(2 e^{-} / 1 \mathrm{H}^{+}\right)$and $-296 \mathrm{mV}\left(2 e^{-} / 0 \mathrm{H}^{+}\right)$. 

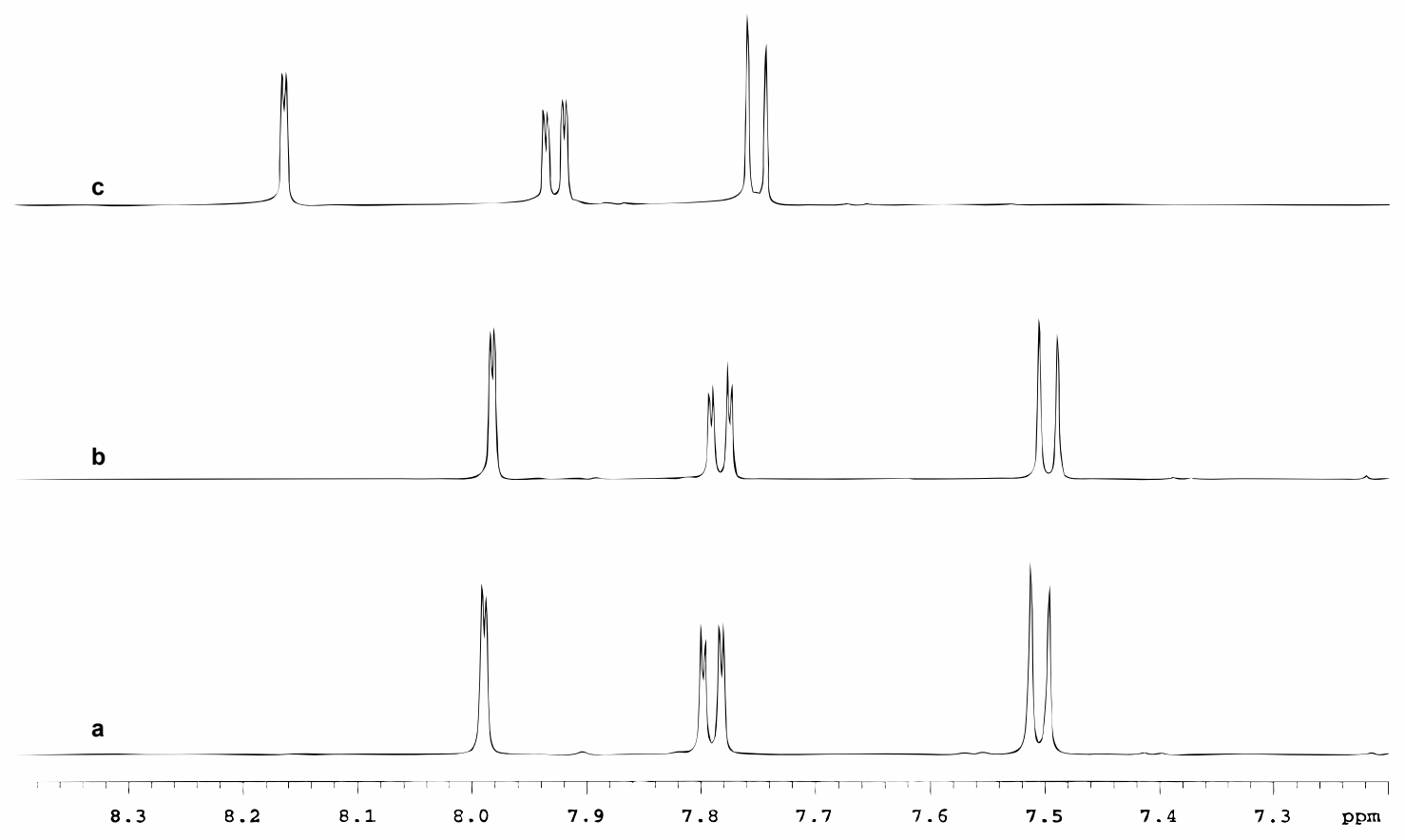

Extended Data Figure $5 \mid{ }^{1}$ H NMR (500 MHz, $D_{2}$ O) spectra. a, Spectrum of AQDS: chemical shift $\delta=7.99$ p.p.m. versus tetramethylsilane (TMS) (doublet (d), coupling constant $J=2 \mathrm{~Hz}$, 1,8 C-H), 7.79 p.p.m. (doublet of doublets, $J=2$ and $8 \mathrm{~Hz}, 4,5 \mathrm{C}-\mathrm{H}), 7.50$ p.p.m. (d, $J=8 \mathrm{~Hz}$, 3,6 C-H). b, The same sample, $20 \mathrm{~h}$ after addition of $\mathrm{Br}_{2} . \mathbf{c},{ }^{1} \mathrm{H}$ NMR of AQDS treated with $2 \mathrm{M}$ $\mathrm{HBr}$ and $\mathrm{Br}_{2}$ and heated to $100{ }^{\circ} \mathrm{C}$ for $48 \mathrm{~h}$. The peaks are shifted due to presence of trace $\mathrm{HBr}$ which shifted the residual solvent peak due to increased acidity. Coupling constants for each peak are identical to $\mathbf{a}$. 


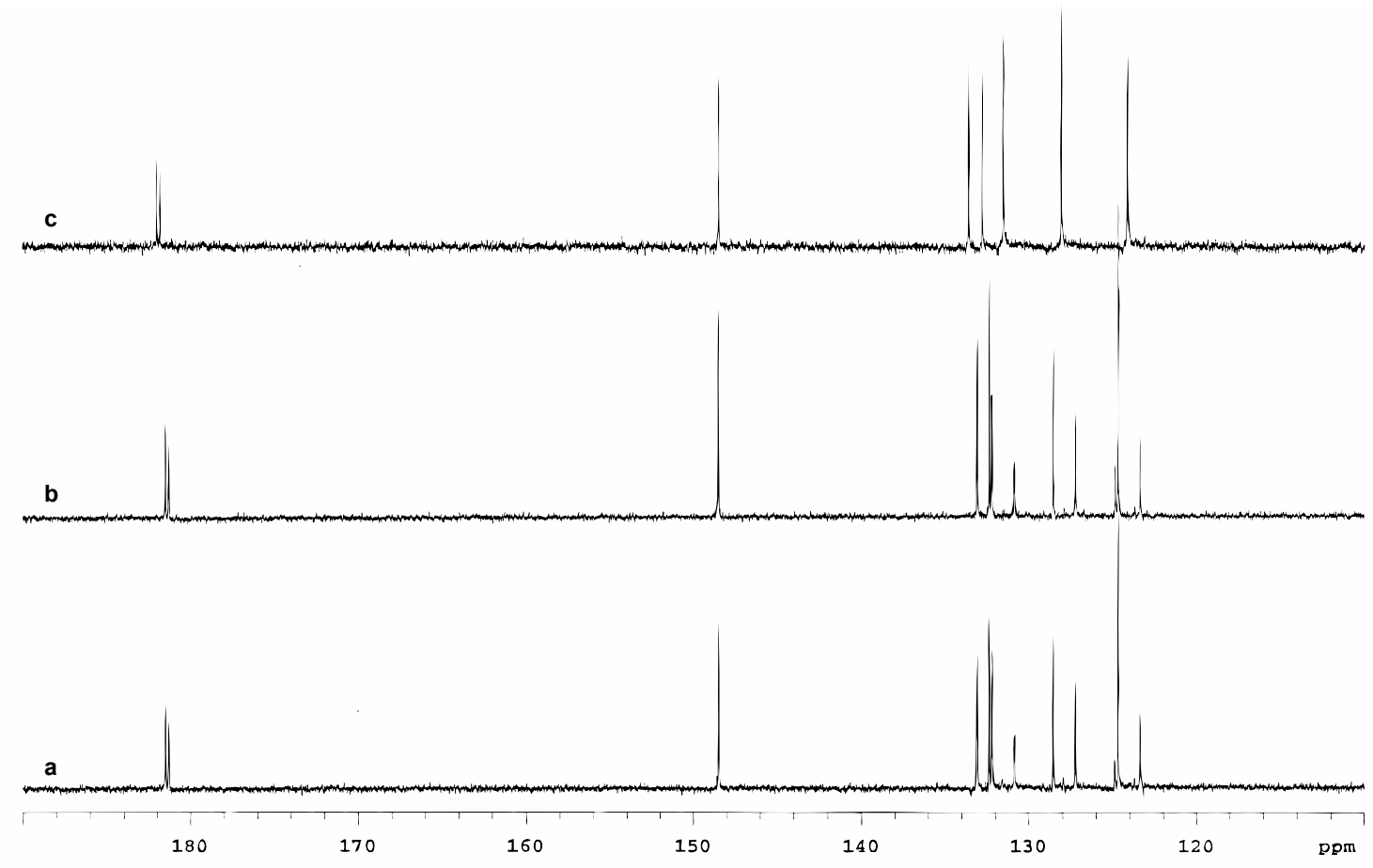

Extended Data Figure 6 $\mid{ }^{13} \mathrm{C}$ NMR (500 MHz, $\left.\mathbf{D}_{2} \mathrm{O}\right)$ spectra. a, AQDS, $\delta=181.50$ p.p.m. versus TMS (C 9), 181.30 p.p.m. (C 10), 148.51 p.p.m. (C 2,7), 133.16 p.p.m. (C 11), 132.40 p.p.m. (C 12), 130.86 p.p.m. (C 3,6), 128.59 p.p.m. (C 4,5), 124.72 p.p.m. (C 1,8). b, The same sample, $24 \mathrm{~h}$ after addition of $\mathrm{Br}_{2} \cdot \mathbf{c},{ }^{13} \mathrm{C}$ NMR of AQDS treated with $2 \mathrm{M} \mathrm{HBr}$ and $\mathrm{Br}_{2}$ and heated to $100^{\circ} \mathrm{C}$ for $48 \mathrm{~h}$. 


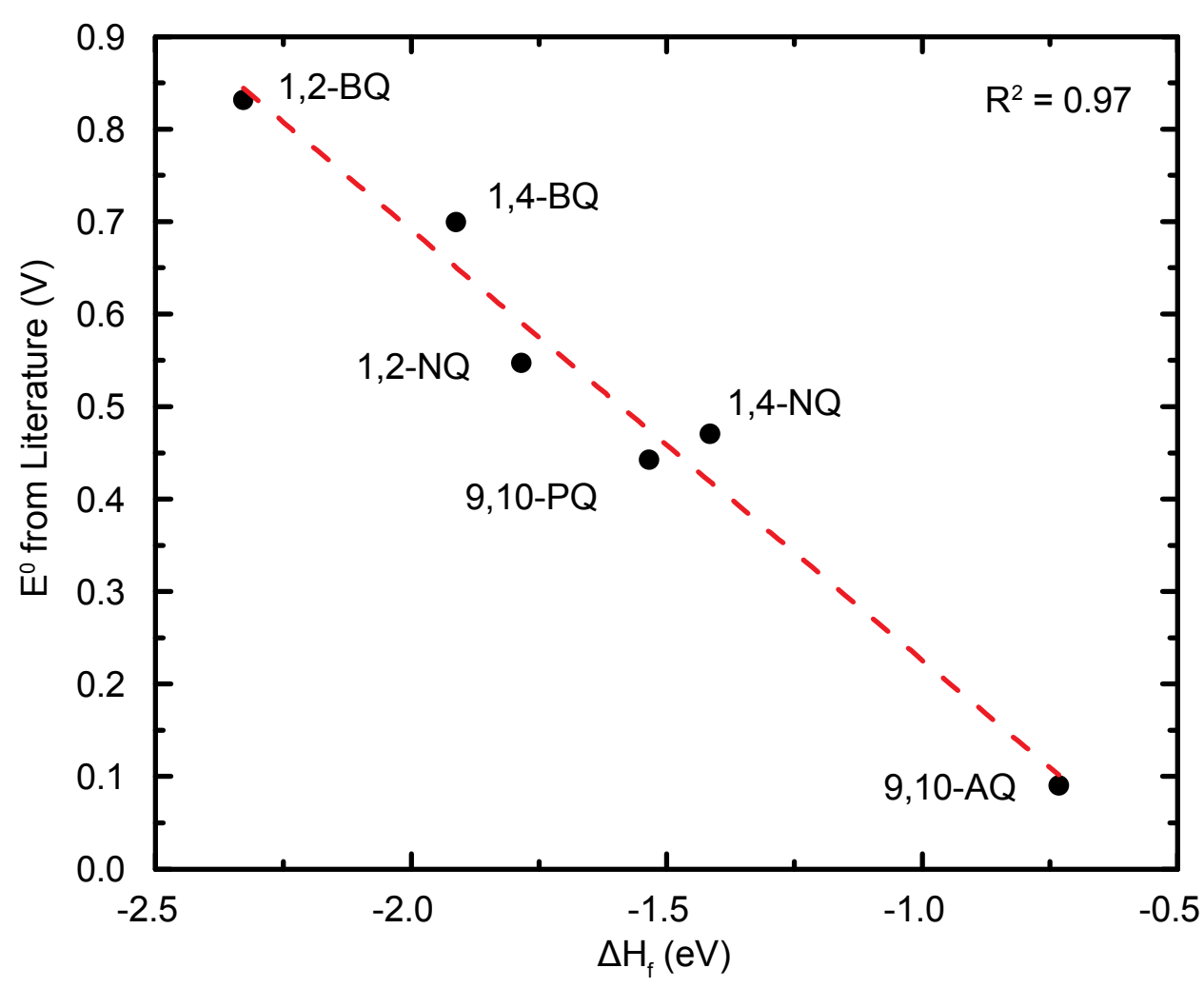

Extended Data Figure $7 \mid$ Calibration model for $\Delta \boldsymbol{H}_{\mathrm{f}}$ and experimental $\boldsymbol{E}^{\mathbf{0}}$. This shows a linear relationship (red dashed line; $R^{2}=0.97$ between calculated $\Delta H_{\mathrm{f}}$ (this work) and experimental $E^{0}$ (from the literature) of six quinones in aqueous solutions: $\mathrm{BQ}$, benzoquinone; $\mathrm{NQ}$, naphthoquinone; $\mathrm{AQ}$, anthraquinone; and $\mathrm{PQ}$, phenanthraquinone. 


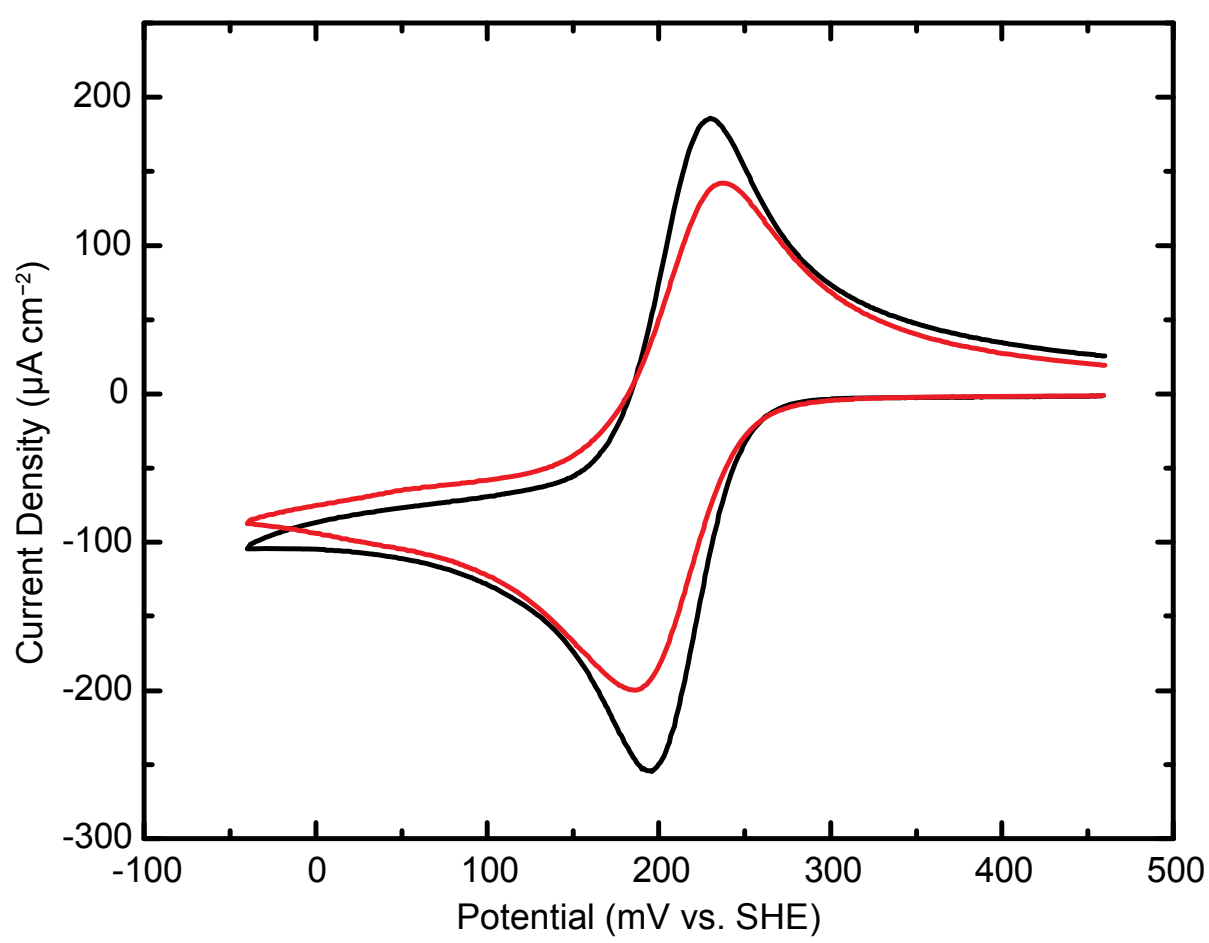

Extended Data Figure 8 | AQDS cyclic voltammograms. Black curve, obtained for a $1 \mathrm{mM}$ solution of AQDS in $1 \mathrm{M} \mathrm{H}_{2} \mathrm{SO}_{4}$ on a stationary glassy carbon working electrode. Red curve, obtained for a crude anthraquinone sulphonation solution containing a mixture of AQDS, 9,10anthraquinone-2,6-disulphonic acid, and 9,10-anthraquinone-2-sulphonic acid diluted to $1 \mathrm{mM}$ total anthraquinone in $1 \mathrm{M} \mathrm{H}_{2} \mathrm{SO}_{4}$. 


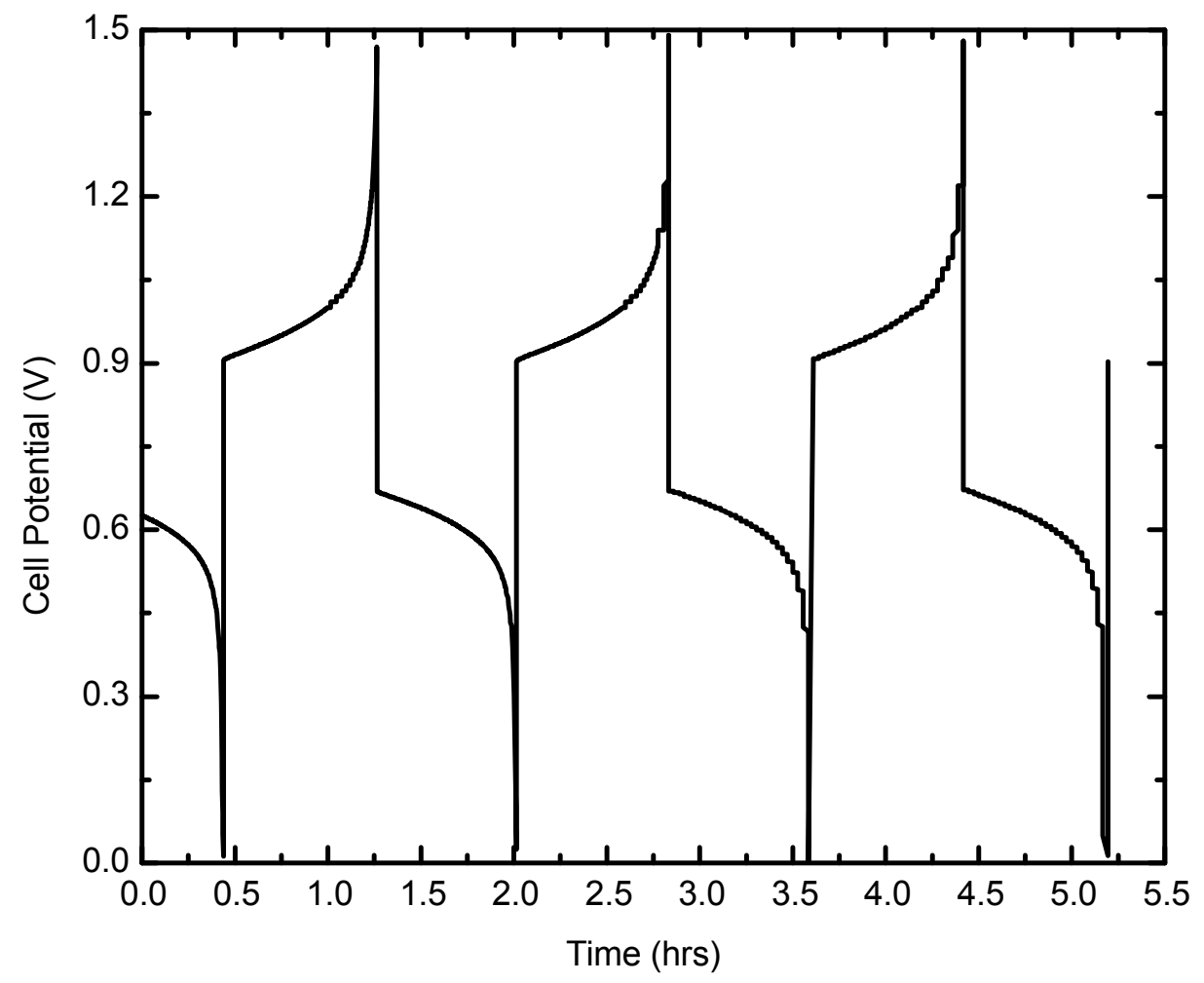

Extended Data Fig. 9 | Flow battery cycling behaviour with $\mathrm{HBr}$ electrolyte on both sides. Data collected by cycling the current at $0.2 \mathrm{~A} \mathrm{~cm}^{-2}$ at $40{ }^{\circ} \mathrm{C}$ using a $2 \mathrm{M} \mathrm{HBr}+0.5 \mathrm{M} \mathrm{Br}_{2}$ solution on the positive side and a $2 \mathrm{M} \mathrm{HBr}+0.1 \mathrm{M}$ AQDS solution on the negative side; cell potential versus time performance is comparable to data in Fig. 2. 
Extended Data Table 1 | AQDS screened by theoretical calculations.

The effect of $-\mathrm{OH}$ substitution on reduction potential and solvation energy.<smiles>[R5]c1c([R5])c(S(=O)(=O)O)c([R5])c2c1C(=O)c1c([R5])c(S(=O)(=O)O)c([R5])c([R5])c1C2=O</smiles>

\begin{tabular}{|c|c|c|c|c|c|c|c|c|c|}
\hline ID & $\begin{array}{c}-\mathrm{OH} \\
\text { substituted }\end{array}$ & $\mathbf{R}_{1}$ & $\mathbf{R}_{\mathbf{3}}$ & $\mathbf{R}_{4}$ & $\mathbf{R}_{\mathbf{5}}$ & $\mathbf{R}_{6}$ & $\mathbf{R}_{\mathbf{8}}$ & $E^{0}(V)$ & $\mathrm{G}_{\text {solv }}^{0}\left(\mathrm{~kJ} \mathrm{~mol}^{-1}\right)$ \\
\hline 1 & Non- & $\mathrm{H}$ & $\mathrm{H}$ & $\mathrm{H}$ & $\mathrm{H}$ & $\mathrm{H}$ & $\mathrm{H}$ & 0.222 & -81.5 \\
\hline 2 & \multirow{3}{*}{ Mono- } & $\mathrm{OH}$ & $\mathrm{H}$ & $\mathrm{H}$ & $\mathrm{H}$ & $\mathrm{H}$ & $\mathrm{H}$ & 0.185 & -81.5 \\
\hline 3 & & $\mathrm{H}$ & $\mathrm{OH}$ & $\mathrm{H}$ & $\mathrm{H}$ & $\mathrm{H}$ & $\mathrm{H}$ & 0.325 & -111.7 \\
\hline 4 & & $\mathrm{H}$ & $\mathrm{H}$ & $\mathrm{OH}$ & $\mathrm{H}$ & $\mathrm{H}$ & $\mathrm{H}$ & 0.108 & -88.2 \\
\hline 5 & \multirow{9}{*}{ Di- } & $\mathrm{OH}$ & $\mathrm{OH}$ & $\mathrm{H}$ & $\mathrm{H}$ & $\mathrm{H}$ & $\mathrm{H}$ & 0.176 & -110.3 \\
\hline 6 & & $\mathrm{OH}$ & $\mathrm{H}$ & $\mathrm{OH}$ & $\mathrm{H}$ & $\mathrm{H}$ & $\mathrm{H}$ & 0.027 & -85.6 \\
\hline 7 & & $\mathrm{OH}$ & $\mathrm{H}$ & $\mathrm{H}$ & $\mathrm{OH}$ & $\mathrm{H}$ & $\mathrm{H}$ & 0.122 & -96.7 \\
\hline 8 & & $\mathrm{OH}$ & $\mathrm{H}$ & $\mathrm{H}$ & $\mathrm{H}$ & $\mathrm{OH}$ & $\mathrm{H}$ & 0.143 & -85.7 \\
\hline 9 & & $\mathrm{OH}$ & $\mathrm{H}$ & $\mathrm{H}$ & $\mathrm{H}$ & $\mathrm{H}$ & $\mathrm{OH}$ & 0.101 & -83.2 \\
\hline 10 & & $\mathrm{H}$ & $\mathrm{OH}$ & $\mathrm{OH}$ & $\mathrm{H}$ & $\mathrm{H}$ & $\mathrm{H}$ & 0.153 & -105.4 \\
\hline 11 & & $\mathrm{H}$ & $\mathrm{OH}$ & $\mathrm{H}$ & $\mathrm{OH}$ & $\mathrm{H}$ & $\mathrm{H}$ & 0.179 & -119.1 \\
\hline 12 & & $\mathrm{H}$ & $\mathrm{OH}$ & $\mathrm{H}$ & $\mathrm{H}$ & $\mathrm{OH}$ & $\mathrm{H}$ & 0.202 & -112.0 \\
\hline 13 & & $\mathrm{H}$ & $\mathrm{H}$ & $\mathrm{OH}$ & $\mathrm{OH}$ & $\mathrm{H}$ & $\mathrm{H}$ & 0.000 & -95.6 \\
\hline 14 & \multirow{10}{*}{ Tri- } & $\mathrm{OH}$ & $\mathrm{OH}$ & $\mathrm{OH}$ & $\mathrm{H}$ & $\mathrm{H}$ & $\mathrm{H}$ & -0.070 & -101.7 \\
\hline 15 & & $\mathrm{OH}$ & $\mathrm{OH}$ & $\mathrm{H}$ & $\mathrm{OH}$ & $\mathrm{H}$ & $\mathrm{H}$ & 0.083 & -116.2 \\
\hline 16 & & $\mathrm{OH}$ & $\mathrm{OH}$ & $\mathrm{H}$ & $\mathrm{H}$ & $\mathrm{OH}$ & $\mathrm{H}$ & 0.187 & -114.3 \\
\hline 17 & & $\mathrm{OH}$ & $\mathrm{OH}$ & $\mathrm{H}$ & $\mathrm{H}$ & $\mathrm{H}$ & $\mathrm{OH}$ & 0.310 & -120.9 \\
\hline 18 & & $\mathrm{OH}$ & $\mathrm{H}$ & $\mathrm{OH}$ & $\mathrm{OH}$ & $\mathrm{H}$ & $\mathrm{H}$ & -0.102 & -91.4 \\
\hline 19 & & $\mathrm{OH}$ & $\mathrm{H}$ & $\mathrm{OH}$ & $\mathrm{H}$ & $\mathrm{OH}$ & $\mathrm{H}$ & 0.089 & -114.0 \\
\hline 20 & & $\mathrm{OH}$ & $\mathrm{H}$ & $\mathrm{OH}$ & $\mathrm{H}$ & $\mathrm{H}$ & $\mathrm{OH}$ & -0.085 & -87.1 \\
\hline 21 & & $\mathrm{OH}$ & $\mathrm{H}$ & $\mathrm{H}$ & $\mathrm{OH}$ & $\mathrm{OH}$ & $\mathrm{H}$ & -0.048 & -102.8 \\
\hline 22 & & $\mathrm{H}$ & $\mathrm{OH}$ & $\mathrm{OH}$ & $\mathrm{OH}$ & $\mathrm{H}$ & $\mathrm{H}$ & -0.107 & -107.8 \\
\hline 23 & & $\mathrm{H}$ & $\mathrm{OH}$ & $\mathrm{OH}$ & $\mathrm{H}$ & $\mathrm{OH}$ & $\mathrm{H}$ & 0.106 & -136.8 \\
\hline 24 & \multirow{9}{*}{ Tetra- } & $\mathrm{OH}$ & $\mathrm{OH}$ & $\mathrm{OH}$ & $\mathrm{OH}$ & $\mathrm{H}$ & $\mathrm{H}$ & -0.098 & -109.0 \\
\hline 25 & & $\mathrm{OH}$ & $\mathrm{OH}$ & $\mathrm{OH}$ & $\mathrm{H}$ & $\mathrm{OH}$ & $\mathrm{H}$ & 0.012 & -108.4 \\
\hline 26 & & $\mathrm{OH}$ & $\mathrm{OH}$ & $\mathrm{OH}$ & $\mathrm{H}$ & $\mathrm{H}$ & $\mathrm{OH}$ & -0.222 & -102.3 \\
\hline 27 & & $\mathrm{OH}$ & $\mathrm{OH}$ & $\mathrm{H}$ & $\mathrm{OH}$ & $\mathrm{OH}$ & $\mathrm{H}$ & -0.019 & -132.3 \\
\hline 28 & & $\mathrm{OH}$ & $\mathrm{OH}$ & $\mathrm{H}$ & $\mathrm{OH}$ & $\mathrm{H}$ & $\mathrm{OH}$ & 0.046 & -114.6 \\
\hline 29 & & $\mathrm{OH}$ & $\mathrm{OH}$ & $\mathrm{H}$ & $\mathrm{H}$ & $\mathrm{OH}$ & $\mathrm{OH}$ & 0.080 & -111.1 \\
\hline 30 & & $\mathrm{OH}$ & $\mathrm{H}$ & $\mathrm{OH}$ & $\mathrm{OH}$ & $\mathrm{OH}$ & $\mathrm{H}$ & -0.259 & -99.0 \\
\hline 31 & & $\mathrm{OH}$ & $\mathrm{H}$ & $\mathrm{OH}$ & $\mathrm{OH}$ & $\mathrm{H}$ & $\mathrm{OH}$ & -0.199 & -91.9 \\
\hline 32 & & $\mathrm{H}$ & $\mathrm{OH}$ & $\mathrm{OH}$ & $\mathrm{OH}$ & $\mathrm{OH}$ & $\mathrm{H}$ & -0.083 & -120.6 \\
\hline 33 & \multirow{3}{*}{ Penta- } & $\mathrm{OH}$ & $\mathrm{OH}$ & $\mathrm{OH}$ & $\mathrm{OH}$ & $\mathrm{OH}$ & $\mathrm{H}$ & -0.252 & -117.1 \\
\hline 34 & & $\mathrm{OH}$ & $\mathrm{OH}$ & $\mathrm{OH}$ & $\mathrm{OH}$ & $\mathrm{H}$ & $\mathrm{OH}$ & -0.292 & -108.3 \\
\hline 35 & & $\mathrm{OH}$ & $\mathrm{OH}$ & $\mathrm{OH}$ & $\mathrm{H}$ & $\mathrm{OH}$ & $\mathrm{OH}$ & -0.030 & -111.6 \\
\hline 36 & Hexa- & $\mathrm{OH}$ & $\mathrm{OH}^{-}$ & $\mathrm{OH}$ & $\mathrm{OH}$ & $\mathrm{OH}$ & $\mathrm{OH}$ & -0.077 & -121.0 \\
\hline
\end{tabular}

